\title{
INCOME AVERAGING AFTER TWENTY YEARS: A FAILED EXPERIMENT IN HORIZONTAL EQUITY
}

\author{
RICHARD SCHMALBECK*
}

\begin{abstract}
After describing the current provisions of the Internal Revenue Code relating to income averaging, Professor Schmalbeck analyzes those provisions from a policy perspective. He concludes that the conventional horizontal equity arguments advanced in defense of income averaging are insubstantial, and that no other policy justification is of sufficient strength to justify the large revenue loss associated with income averaging. Although outright repeal of the averaging provisions may be the best solution, Professor Schmalbeck also explores several more modest amendments to the averaging provisions.
\end{abstract}

Two durable fixtures of the federal income tax are its annual accounting requirement and its graduated rate structure. ${ }^{1}$ The presence of these two features is thought to generate a horizontal equity problem between two groups of taxpayers: those whose incomes fluctuate widely from year to year and those who enjoy a relatively steady flow of income. Horizontal equity demands that taxpayers who have equal incomes be taxed equally. A progressive mcome tax assessed annually, however, will tax an individual with a lifetime income of $50 x$ more heavily if his mcome pattern consists of alternating years of zero income and $2 x$ income than if his income were $x$ in each year. ${ }^{2}$

* Professor of Law, Duke University. I am grateful to my research assistants David Cohen, Eileen Mallon, and Barbara Tobin who, despite their fervent hopes that they will be averaging their own incomes soon, have given unstimtingly in aid of iny criticisms of mcome averaging. I am also grateful to Marvin Chirelstein, Charles Clotfelter, Walter Dellinger, Painela Gann, Robert Hartman, Thomas Rowe, and Patricia White for their helpful comments on an earlier draft of this article. Fimally, I am grateful to the Duke University Law School for awarding me a Eugene $T$. Bost Research Professorship for the Fall 1983 semester, when the research for this article was accomplished.

1. The durability of the graduated rate structure may be debatable, but I believe it will survive. Even the advocates of so-called "flat rate" tax structures liave generally proposed rate schedules that have several graduated brackets. The most significant proposal, the BradleyGephart bill, S. 1421, 98th Cong., 1st Sess., 129 CoNG. Rec. S7837 (daily ed. June 8, 1983), has, in effect, four brackets with rates ranging from 0 to $30 \%$.

2. This will be true if the other factors affeeting tax hability-for example, fanily size, deductions, credits-are the same for both taxpayers, and if an incoine of $2 x$ is exposed to a higher rate of tax than is an income of $x$. It is not intuitively obvious to everyone that a taxpayer whose income fluctuates will, absent relief, pay a higher lifetine tax than he would if his income were steady. In the example in the text, he will pay more tax in years when lis income is $2 x$, but less $\operatorname{tax}$ in years when his income is 0 . How do we know that the net of these greater and lesser $\operatorname{tax}$ 
The penalty associated with incoine fluctuation can be quite severe. The inagnitude of the fluctuation penalty ${ }^{3}$ obviously varies with the degree of fluctuation. However, to give an example, a taxpayer with a two-year incoine of $\$ 40,000$ would pay nearly sixty percent more tax if he received that income entirely in one year than he would if he had received an incoine of $\$ 20,000$ in each of two years. ${ }^{4}$

Prior to 1964, Congress made only piecenneal responses to this problem. ${ }^{5}$ In 1964, however, after prolonged debate among tax analysts, ${ }^{6}$ and in response to President Kennedy's request, ${ }^{7}$ Congress enacted, in the Revenue Act of 1964,8 general incone averaging provisions that apphed to any eligible electing taxpayer whose current year's incoine was sufficiently greater-as defined by the statute-than his average incoine over the preceding four years. Those provisions

amounts inevitably results in higher total tax? An informal proof follows: If we break down an income of $2 x$ into two tiers -the first $x$ dollars of income and the next $x$ dollars of income-we can compute the rates of tax, $r_{1}$ and $r_{2}$, respectively, that each tier is exposed to. These may be single marginal rates, or composites of several marginal rates, if an income of $x$ is large enough to spread across inore than one marginal bracket. Since we have assumed a progressive tax, we know that $r_{1}<r_{2}$. Comparing our fiuctuating-income taxpayer to another taxpayer whose income is $x$ every year, we can see that the tax savings of our fluctuating-income taxpayer in years of 0 income will be $x r_{1}$, and the tax penalty in years of $2 x$ income (the additional tax paid over what the steady-income taxpayer pays) will be $x r_{2}$. Since $r_{1}<r_{2}$, then $x r_{1}<x r_{2}$. The tax saved in lean years, then, is systematically less than the extra tax paid in the high-incoine years, and there is thus a net penalty for having a fluctuating income exposed to a progressive tax.

3. "Fluctuation penalty" is not a tern of ant, but will be used throughout this article to mean the difference between the tax habihity on any specified strean of annual taxable incomes and the tax liability that would have been incurred had the same total taxable income been received over the saine period in equal annual amounts.

4. I.R.C. $§ 1(a)(3)$ (1982). This coinputation and all subsequent tax computations in this article, unless otherwise noted, are based on taxable income on a joimt return filed for a tax year beginning im 1984. The total tax on two years of $\$ 20,000$ mcone would he $\$ 4922$; on an income of $\$ 40,000$ received in a simgle year, the tax would be $\$ 7858$, or $59.7 \%$ more.

5. See, e.g., Act of Aug. 16, 1954, cl. 736, 68A Stat. 348 (codified at 1.R.C. $\$ 1341$ (1982) (providing rehief to the extent that a fluctuation in income is caused by the repayment of an amount received in a prior year under a claim of right)).

6. See, e.g., Carroll, Fluctuating Income, in STAFF OF House COMM. ON WAYS AND MEANS, 86th Cong., Ist Sess., 1 TaX Revision Compendium of Papers on Broadening the TaX Base 629, 629 (Comm. Print 1959) [hereinafter cited as TAX Revision Compendium) (suggesting that fiuctuation penalty would only be relieved by a reduction in degree of progression of tax rates); Hart, Averaging Taxable Income, in TAX Revision CoMpendium 645, 660 (suggesting simple averagimg over five to seven years); Newman, Taxation of Fluctuating Income, in TAX REv1sION COMPENDIUM 669, 672 (suggesting lifetime averaging system); Steger, Averaging Income for Income Tax Purposes, TAX Revision CoMpendium 589, 599 (suggesting short-term optional averaging device).

7. See President's 1963 Tax Message, reprinted in 1963 U.S. Code Cong. \& AD. News 1429, 1438-39.

8. Pub. L. No. $88-272, \S 232,78$ Stat. $19,105-12$ (1964) (codified as amended at 1.R.C. $\S \S 1301-1305$ (1982)). 
were substantially simplified by the Tax Reform Act of $1969^{9}$ and are now widely used by taxpayers. More than six and a half million returns filed for the 1981 tax year ${ }^{10}$ included an election to apply income averaging, resulting in an aggregate savings to the electing taxpayers of nearly four billion dollars. ${ }^{11}$ The loss of revenue by itself deinonstrates the importance of the income averaging provisions in our present Internal Revenue Code (Code). In fact, the revenue importance of income averaging has led to very recent amendments to the income averaging provisions intended to inake averaging less costly to the Treasury as a means of reducing the federal budget deficit. ${ }^{12}$ In addition, income averaging provides an interesting case study in the ways in which pursuit of a fundamental but highly elusive tax pohicy goal-horizontal equity-can go awry.

This article provides an explanation and analysis of how the income averaging provisions work, followed by an assessment of how well they serve the traditional tax policy goals of fairness, efficiency, administrability, economic stabilization, and revenue raising. Because income averaging was added to the Code almost entirely out of fairness considerations, the bulk of this section will be devoted to issues arising

9. Pub. L. No. 91-172, $\S 311,83$ Stat. $487,586-88$ (1969) (codified as amended at I.R.C. $\S 1302(1982)$ ). The primary simplification of income averaging provisions resulted from elimination of the requirement that capital gains, income from gifts, and gambling income be excluded from the ambit of averaging.

10. INTERNAL ReVEnUE SERvice, Statistics of InCOME - 1981, Individual InCOME TAX RETURNS 72 (1983) (Table 3.1, col. 1) [heremafter 1981 STATISTICS OF INCOME]. This table presents an IRS estimate, based on a sampling of actual returns, that 6,569,730 returns reflected an income averaging election in 1981. This represents about $6.9 \%$ of all individual returns filed.

11. Id. at 73 (Table 3.1, col. 17). The IRS estimate of the savings was $\$ 3,919,441,000$. In fact, this estimate may be a modest overstatement of the net taxpayer savings from income averaging, because the election of income averaging requires that the taxpayer forego certain other elections that might, in the absence of averaging, have reduced a taxpayer's tax liability below the statutory amount. See I.R.C. $\$ 1304$ (b) (1982). By far the most significant of these foregone opportunities, however, was the ability to use the maximum tax provisions that were, until 1981, embodied in I.R.C. $\S 1348$. With the reduction in maximum rates accomplislied by the Economic Recovery Tax Act of 1981, Pub. L. No. 97-34, § 101(c), 95 Stat. 172, 183, repealing I.R.C. $\$ 1348$ (1976), the maximum tax was repealed. Because the other elections barred by I.R.C. $\$ 1304$ (b) (1982) relate to income earned by U.S. citizens or residents living abroad, I.R.C. $\$ 911$ (1982), and income from United States possessions, I.R.C. \& 93I (1982), it seems safc to conclude that the election of income averaging no longer entails any significant foregone opportunities for most taxpayers.

12. On July 18, 1984, sliortly before the final printing of this issue, the President signed into law the Tax Reforn Act of 1984, enacted as Division A of the Deficit Reduction Act of 1984, Pub. L. No. 98-369, § I73, 98 Stat. 494, 703-04 (1984) (amending I.R.C. $\S \S ~ 1301-1302$ (1982)). The modifications to imcome averaging contained in this legislation are explained and briefly analyzed in section V of this article, styled "Afterword."

Attention has also focused on complete repeal of income averaging as a possible deficit-reducing option. See Congressional Budget Office, Reducing the Deficit: Spending and Revenue Options 312-13 (1983); S. Rep. No. 2062, 98th Cong., 1st Sess. 41 (1983); M. Brown, TAX ChOICES 35-37 (1983). 
under that criterion. The section concludes that the incoine averaging system is largely unnecessary, perhaps even counterproductive. Although outright repeal of income averaging is probably the most satisfactory remedy, this article concludes by exainining several more modest legislative changes that could significantly improve the existing systein.

\section{Explanation and Analysis of Income Averaging}

\section{A. The Averaging Computation.}

Sections 1301 through 1305 of the Code allow eligible taxpayers to elect a tax coinputation inethod that is based on the taxpayer's income in the tax year for which the return is being prepared (the "computation year"13) and the income in the preceding four tax years (the "base period"14). This is a "rolling" averaging system, so if a taxpayer contimues to be ehgible, he may elect to employ the averaging provisions in any number of consecutive years. Each new tax year can be a computation year, with the new base period consisting of the previous year's computation year plus the preceding three tax years. The averaging mechanism operates with respect to a taxpayer's total taxable income. It requires first computing "averagable income,"1s which is the amount by which taxable incoine in the computation year exceeds thirty percent of total base-period taxable income, ${ }^{16}$ and then applying to that averagable income the marginal tax rate or rates that would have applied had that averagable income been received evenly over the fiveyear period (the four base-period years plus the computation year), in addition to an income in each of those years equal to thirty percent of the base-period income. ${ }^{17}$

As the preceding discussion may suggest, it is extremely difficult to describe the income averaging computations accurately without falling into the soporific syntax of the instructions found on tax forins: Take the excess of this over twice the anount of that, and multiply the result by some other apparently arbitrary amount. After even a few such

13. I.R.C. $\S 1302(c)(1)$ (1982).

14. I.R.C. $\S 1302$ (c)(2) (1982).

15. I.R.C. $\S 1302$ (a) (1982).

16. I.R.C. $§ 1302(\mathrm{a})(1)$ (1982) defines averagable income as that part of the taxable income in the computation year which exceeds $120 \%$ of average base-period income, and I.R.C. $\S 1302(b)(1)$ (1982) defines average base-period income, logically enough, as one-fourth of the sum of the incomes in the four base-period years. I have collapsed these two provisions in the text for simplicity into a single computation using $30 \%$, which is simply one-fourth of $120 \%$.

17. I.R.C. $\S 1301$ (1982). 
steps, the intuitive thread running through inany Code provisions-including the ones under discussion here-becomes hopelessly tangled.

The intuitive thread here, though, is really quite straightforward. A taxpayer who has for several years earned a salary of $\$ 10,000$ will note a dramatic increase in her marginal tax rate if she wins $\$ 100,000$ in a lottery. Much of that income will be taxed at rates as high as fortyfive percent. ${ }^{18}$ But if the taxpayer is allowed to divide the extra amount into five $\$ 20,000$ slices, and to compute her tax as though one slice had been received in each of the five most recent tax years, then the lottery winnings will be taxed at the substantially lower rates that apply to incremental mcounes between her $\$ 10,000$ normal income and a hypothetical $\$ 30,000$ income. ${ }^{19}$

Income averaging under the Code approximates the latter result, but not uniformly so. Illustration of the imperfections of the present averaging device requires a slightly inore elaborate model-one that will be explained with something approaching technical accuracy. Imagine a graduated rate structure of the most elementary sort: one that taxes the first $\$ 10,000$ of taxable income at a marginal rate of ten percent and all taxable income above $\$ 10,000$ at a marginal rate of twenty percent. Table I presents the taxable income of a hypothetical taxpayer over a five-year period; column 3 of that table presents the tax computed under the rate structure given above if there were no averaging provisions.

\section{Table I}

\begin{tabular}{|c|c|c|c|}
\hline$\underline{1}$ & $\underline{2}$ & $\frac{3}{1}$ & $\underline{4}$ \\
\hline Year & Income & Tax w/o Averaging & Tax w/Averaging \\
\hline $\begin{array}{l}1 \\
2\end{array}$ & $\begin{array}{r}\$ 3000 \\
4000\end{array}$ & $\begin{array}{r}\$ 300 \\
400\end{array}$ & $\begin{array}{r}\$ 300 \\
400\end{array}$ \\
\hline 3 & 6000 & 600 & 600 \\
\hline 4 & 7000 & 700 & 700 \\
\hline 5 & 30,000 & $\underline{5000}$ & $\underline{3400}$ \\
\hline Total & 50,000 & 7000 & 5400 \\
\hline
\end{tabular}

Applymg the mcome averaging provisions to this income pattern would first involve computing the averagable income. This is the computation-year income of $\$ 30,000$, minus thirty percent of the base-period income (which totals $\$ 20,000$ ). Averagable income is thus $\$ 24,000$

18. For taxable years beginning in 1984 , a $45 \%$ rate applies to all taxable income between $\$ 85,600$ and $\$ 109,400$ for taxpayers filing joint retums. I.R.C. $\$ 1(a)(3)$ (1982).

19. Taxable income between $\$ 10,000$ and $\$ 30,000$ on a 1984 joint return is exposed to a series of rates ranging from $14 \%$ to $28 \%$. Id. 
$(\$ 30,000-\$ 6,000)$. This $\$ 24,000$ is then divided into five equal slices of $\$ 4800$ each. These $\$ 4800$ increments are taxed as thougln they were received in each year in addition to $\$ 6000$, which is thirty percent of base-period income. Thus, the tax on the $\$ 4800$ increinents is computed as though that amount were the last $\$ 4800$ of a $\$ 10,800$ ineome. Under the stipulated rate schedule, the tax rates applied to the $\$ 4800$ increinents would be ten percent of the first $\$ 4000$ plus twenty percent of the last $\$ 800$, producing a tax on each increinent of $\$ 560$.

Because these increments of averagable incoune have never been taxed before, all five inust be taxed in the computation year. In addition, that part of the computation year's incoine which was not averagable incoine must also be taxed. Thus, the tax in the coinputation year under the Code's averaging inechanisin is five times $\$ 560$, plus the $\$ 600$ of tax computed on the $\$ 6000$ of nonaveragable income. This amount is shown in column 4 of Table $I$.

This example illustrates several aspects of income averaging mechanics that seem worth noting at this point, although their full significance will not be considered until later in this article. First, this inechanisin provides no immediate relief in situations where income in the coniputation year declines from the four-year base-period average. In such a case, there is simply no averagable incoine to be spread back to those base-period years. This seems odd because the tax penalty imposed on fluctuating incoines is symmetrical: generally, income flows of $2 x$ and zero in a two-year period will be taxed inore heavily than income flows of $x$ in each year, and the alnount of the penalty will be the same regardless of whether the year of zero income precedes or follows the year with incoine of $2 x$. The present income averaging scheine, lowever, permits taxpayers to spread income froin a current high-inconie year back to prior low-income years, but not to spread the effects of prior high-income years forward to a current low-income year.

This anomaly in the federal incoine-averaging system was not specifically proposed by any of the proponents of averaging who appeared before Congress prior to the 1964 adoption of the averaging system.20 Nor has it inet with the approval of tax commentators since. ${ }^{21}$ The stat-

20. Indeed, the experts who proposed fully-articulated income-averaging systems would have included downward fluctuations. See, e.g., Carroll, supra note 6, at 633; Dickerson, Taxation of Fluuctuating Income, TAX REvision CoMPENDIUM, supra note 6, at 621, 625; Kragen, Effect of Taxation on Individuals with Fluctuating Incomes, supra note 6, at 579, 584-85.

21. See, e.g., David, Groves, Miller \& Wiegner, Optimal Choices for an Averaging System-A Simulation Analysis of the Federal Averaging Formula of 1964, 23 NAT'L TAX J. 279 (1970); Ferguson \& Hood, Income Averaging, 24 TAX L. REv. 53, 93 (1968)("Perhaps the most serious inadequacy in the 1964 legislation is the lack of provision for downward fluctuations in income."); 
utory history of income averaging is silent on the question of why Congress chose to treat a symmetrical problem with an asymmetrical solution. ${ }^{22}$ Several explanations, however, can be imagimed. First, the present system, under which the computation year will always be a year of relatively high income, has some modest conveniences for the tax systein. That year will be one in which a relatively high tentative tax hability will exist, ${ }^{23}$ which may be reduced, but not below zero, by averaging. No opening of prior returns is required, nor will there be any refunding of tax liabilities already collected in prior years. ${ }^{24}$

But these advantages turn out to be extremely modest in view of the fact that the Treasury seems to have hittle problem handling a refunding of previously collected taxes im other areas, such as net operating losses. ${ }^{25}$ Furthermore, the tax withholding provisions do not take cognizance of the possibility of income averaging. ${ }^{26}$ Thus, with withholding based on the current income in the relatively high-income year, it is likely, even under the present system, that the full ainount of the tax savings resulting from income averaging will have already been col-

Goldberg, Income Averaging Under the Revenue Act of 1964, 74 YALE L.J. 465, 467 (1965); Klein \& Wiegner, Income Averaging for Tax Purposes-Sources of a Statutory Solution, 60 Nw. U.L. REv. 147, 159-61 (1965).

22. H.R. REP. No. 749, 88th Cong., lst Sess. 109 (1963).

23. That is, absent averaging, the tax determined under I.R.C. $\S 1$ (1982) would be relatively high.

24. See Steurele, McHugh, \& Sunley, Who Benefits from Income Averaging?, 1 NAT'L TAX J. 19,27 (1978) [hereinafter cited as Steurele].

25. I.R.C. $\$ 172$ (1982) permits taxpayers to spread business losses backward for up to three years (and forward for up to fifteen years), which typically results in a refunding of prior tax payments; see also infra note 230 and accompanying text.

26. The federal income tax withholding provisious, I.R.C. $\$ \S 3401-3403$ (1982), and the regulations thereunder, specify amounts to be withheld from wages on the basis of the amount and timing of those payments without regard to what the taxpayer's income in prior years may have been. I.R.C. $\$ 3402(f)(1982)$ permits a taxpayer to adjust his withholding by providing estimates of unusual deductions on Form W-4. That form, however, provides no opportunity to reflect a taxpayer's expectation that his ultimate tax habihity will be lowered by incoine averaging.

Of course, many taxpayers elect to use incoune averaging because they receive large amounts of income that, like royalties or capital gains, may not be subject to withholding. Such taxpayers are likely to be subject to an obligation under I.R.C. $\S 6015$ (1982) to make estimated tax payments. Like Form W-4, the estimated tax form (Form 1040-ES) does not provide an opportunity to reflect the fact that the taxpayer's ultimate tax liability inay be lowered by income averaging. As a practical matter, however, many taxpayers who are technically obligated to make estimated tax payments mcur no penalty for their failure to do so because they qualify for one or more of the exceptions in I.R.C. $\$ 6654$ (d) (1982), which bar assessment of the penalty under I.R.C. $§ 6654$ (a) (1982) for failure to pay estimated tax. Thus, it can be presumed that a considerable number of averaging taxpayers, whose computation-year incounes are relatively high due to receipts from sources that are not subject to withholding, will not be in a situation where averaging will necessarily generate a refund check in the year after the tax year in whicls averaging was elected. 
lected ${ }^{27}$ and will have to be refunded to the taxpayer after the return is filed. ${ }^{28}$ Thus, from a cash-flow viewpoint, the averaging system is likely to involve mailing checks to taxpayers out of tax already collected. Nevertheless, the fact that the administrative conveniences of allowing averaging only in relatively high-income years seem highly ephemeral is far from conclusive proof that Congress did not enact those particular averaging provisions to further those putative conveniences.

There exists, however, another explanation for this asymmetry. Congress may have intended income averaging to provide relief only to taxpayers with oscillating incomes-incones that have cycles, but not annual cycles. A taxpayer who, for example, spends every even-numbered year writing the first half of a book that he coinpletes and sells in every odd-numbered year will not necessarily be disadvantaged by an averaging systein that permits him to elect to average only in the oddnumbered years. He inay still be able to shift incoine from years with relatively high rates to years with lower rates. ${ }^{29}$ Only the taxpayer who has a one-time, permanent decrease in incoine level will never have a high-inconse year to use as a coinputation year to obtain the benefits of spreading incoine to achieve a leveling of inarginal rates. It is possible that Congress simply did not wish to extend the benefits of averaging to this class of taxpayers, especially since this class would include nost taxpayers at the point of their retirement froin the labor force, and would thus be large in number.

Even as to upward fluctuations the federal averaging inechanism typically provides only partial relief from the tax penalty associated with irregular income flows. For exanuple, if the hypothetical taxpayer whose incoine is shown in Table I had received his five-year incoine of $\$ 50,000$ in even annual amounts of $\$ 10,000$ per year, his total tax over

27. The average taxpayer typically finds himself in a position to receive a tax refund at yearend in any case. In 1981, for example, more than three-quarters of all returns reflected overpayment of the tax liability computed. 1981 STATISTICS OF INCOME, supra note 10, at 89 (Table 3.6, cols. 51,57). Although there is no breakdown available with respect to taxpayers electing income averaging, it seems likely that, because the tax advantage of averaging was not reflccted in thcir withholding, they are more likely than inost taxpayers to have received a refund.

28. Taxpayers can, of course, elect to apply overpayments to the following year's estimated tax liability. However, over $97 \%$ of overpayments are returned to taxpayers, rather than credited to estimated tax. See, e.g., 1981 Statistics of INCOME, supra note 10, at 89 (Table 3.6, cols. 51, 53).

29. Of course, if the cycles of income have phases that exceed five years in length, complete balancing of the rates through averaging may not be possible. It is also true that the prcsent mechanics appear to be less effective at relieving the bracket effect of one-time "valleys" in a taxpayer's income stream than they are at relieving the comparable effects of one-time "peaks." See infra note 185 and accompanying text. 
the five-year period would have been $\$ 5000$, rather than the $\$ 5400$ total produced by the section 1301 computations. Those computations would have saved him $\$ 1600$ of the $\$ 2000$ penalty that he otherwise would have incurred for having a fluctuating income. Although the taxpayer would recoup eighty percent of the fluctuation penalty in this case, the proportion of the fluctuation penalty that is relieved by the averaging provisions is not consistent. The averaging provisions are not directly focused on the fluctuation penalty at all and, in fact, the percentage of the penalty that can be recouped under these provisions can vary from zero to one hundred percent. ${ }^{30}$

Thus, not only is the rehef provided by averaging from the overtaxing of fluctuating incomes uneven, but, worse still, that unevenness is completely unprincipled. The computational source of this unevenness is that the Code formula inflates the base-period imcome by using thirty percent of base-period income to determine averagable imcome, ${ }^{31}$ when the true average of base-period income is simply one-fourth of the four-year total. When the averagable income is then spread over the total five-year period, it is stacked on top of this inflated base-period number. This may cause all or some of the averagable income to be cxposed to a higher marginal rate than it would under a perfect averaging system. ${ }^{32}$

This computational feature of the present income averaging system is not the result of an oversight. Indeed, as the averaging provisions were originally enacted in $1964,{ }^{33}$ the problem was even greater, with one-third of base-period income constituting the "unaveragable" anount. ${ }^{34}$ The committee reports concerning the Tax Reform Act of $1969,{ }^{35}$ which reduced the percentage of base-period income that would be unaveragable, offer an explanation of Congress's original purpose in

30. Although it is possible to reach zero and $100 \%$ penalty reduction outcomes under the actual statute, either extreme is an unlikely special case. The extreme cases can be illustrated as follows: A $100 \%$ penalty reduction would occur where a single taxpayer had taxable mcome of $\$ 5000$ in a 1984 computation year, and $\$ 1000$ in taxable mcome for each base-period year. Such a taxpayer would have a $\$ 325$ fluctuation penalty, all of which would be eliminated by income averaging. On the other hand, a taxpayer with an mcome of $\$ 55,000$ in 1984 and $\$ 35,000$ in each base-period year would incur a fluctuation penalty of $\$ 1000$, none of which would be relieved by income averaging.

31. I.R.C. $§ 1302(a)$ (1982). More precisely, the formula uses 120\% of average base-period income, rather than $30 \%$ of total base-period income. See supra note 16.

32. By "perfect averaging system," I inean one that completely reheves all fluctuation penalties.

33. Revenue Act of 1964, Pub. L. No. 88-272, § 232(a), 78 Stat. 19, 105 (codified as annended at I.R.C. $\S \S 1301-1305$ (1982)),

34. Again, the statute spoke in terms of $133 \%$ of average base-period incoine, rather than one-third of total base-period income. See supra note 16.

35. Pub. L. No. 91-172, § 311,83 Stat. 487, 586-88 (1969). 
setting the unaveragable amount above the twenty-five percent level that would be necessary for consistently full relief of the fluctuation penalty:

The [one-third of average base-period income] was included in the general income averaging adopted in 1963 [the Revenue Act of 1964], in part because it was believed it was necessary to limit for administrative reasons the availability of a new and unfamiliar provision to those cases where it was needed most. ${ }^{36}$

The report further notes that greater familiarity with the provision from a tax administration view had "reduced the significance of this consideration." 37 But apparently the significance was not reduced to zero, because the 1969 ainendinents, which are reflected in the present Code, do not eliminate the unevenness and the incompleteness of income averaging relief.

This seems odd at first. If Congress has decided that taxpayers with fluctuatimg incomes and those with level incoines should bear equivalent burdens, why would it arrange a system that relieves some, but not all, of the fluctuation penalty and im so irregular a manner? Congress of course does sometimes decide that fairness dictates a particular kind of relief, but that the fisc can only afford so inuch relief. ${ }^{38}$ That would not seein to be the case here, however. At the time that the thirty percent of base-period income provision was adopted, incoine averaging was little used and rather inexpensive from a revenue viewpoint. ${ }^{39}$ Even if liberalization had somewhat increased the availability and attractiveness of averaging, it would hardly have been thought a serious revenue problem at that time.

There is, of course, a lurking tax admimistration problem of enormous proportions im what might be called "perfect averaging" systeins-those $\mathrm{m}$ which every dollar of the fluctuation penalty is returned to the taxpayer. The fluctuation penalty is measured by reference to a paradigmatic taxpayer who does not exist: the taxpayer whose income never varies from year to year. ${ }^{40}$ If nearly every taxpayer incurs soine

36. H.R. Rep. No. 413,91 st Cong., 1st Sess. 85 (1969).

37. $I d$.

38. For example, the "marriage penalty" deduction in I.R.C. $§ 221$ (1982) reduces, but does not eliminate, that penalty.

39. At the time of the 1969 legislation, Congress estimated that the mcome-averaging provision would cost the Treasury only $\$ 300$ million in lost revenues annually. See H.R. ReP. No. 413 , 91st Cong., Ist Sess. 254 (1969); S. ReP. No. 552, 91st Cong., 1st Sess. 119 (1969).

40. Technically, the paradigm is the taxpayer whose imcome varies witlin a sufficiently narrow range that his top marginal rate is the same year after year, so that there is no income shifting among tax years that would produce a lower total tax. It is doubtful that there are many such taxpayers, except those who are well into the top bracket; for the latter group, even substantial income fluctuations may not change their marginal rate. 
fluctuation penalty, then the term is something of a misnomer. Only that part of this amount that is unusual deserves to be called a penalty; and, for tax administration purposes, mcome averaging would be a cumbersome way to distribute a tax cut to every taxpayer. Congress can appropriately choose to ensure that not every taxpayer will be able to benefit from income averaging, and it has essentially two means available to do this. It can provide a computation formula that limits access-as it has done in using thirty percent of base-period income as the nonaveragable annount. Alternatively, Congress could control the eligibility in some way extrinsic to the essential averaging mechanism. As the next section makes clear, Congress has employed both approaches. The irregularity of the relief that Congress lias devised can only be interpreted as an unintentional and incidental effect of the metlods used to limit, for administrability reasons, the availability of averaging.

\section{B. Eligibility for Income Averaging.}

Generally speaking, any individual taxpayer is eligible to elect income averaging in any tax year in which his income is greater than thirty percent of his total income over the preceding four tax years. There are four basic exceptions to this rule, generally disqualifying four types of taxpayers: nonresident aliens, ${ }^{41}$ taxpayers making certain other elections under the Code, ${ }^{42}$ taxpayers having no more than $\$ 3000$ of averagable income, ${ }^{43}$ and individuals who received substantial support from others during their particular base years. ${ }^{44}$

1. Nonresident Aliens. Taxpayers who are nonresident aliens at any time during eitler the computation year or the four-year base period may not elect income averaging in the coinputation year. ${ }^{45}$ For this purpose, determination of nonresident alien status is made in accordance with the provisions of the Code dealing with the income tax treatment of nonresident aliens generally. ${ }^{46}$

41. I.R.C. § 1303(b) (1982); see also I.R.C. § 1303(a) (1982).

42. I.R.C. $\& 1304$ (b) (1982).

43. I.R.C. $\S 1301$ (1982). Obviously, this himitation could be viewed as either a part of the basic averaging computation or as an eligibihty criterion. I prefer the latter characterization, because the $\$ 3000$ operates simply as a threshold; taxpayers who fail to satisfy this requirement may not elect averaging, while otherwise eligible taxpayers who do satisfy this requirement may so elect. In the latter case, the computation of tax $\mathrm{m}$ the computation year proceeds as described $\mathrm{m}$ the preceding section, with no further reference to the $\$ 3000$ minimum.

44. I.R.C. $\S 1303$ (c) (1982).

45. I.R.C. $\S 1303$ (b) (1982).

46. Treas. Reg. $\$ 1.1303-1$ (b) (1983) provides specifically that nonresident alien status is to be determined under Treas. Reg. $\$ \S 1.871-2$ to -4 (1983). The legislative history of the mcome-aver- 
2. Taxpayers Making Disqualifying Elections. At various times, Congress has decided not to allow a taxpayer to obtain simultaneously the advantages of incoine averaging and the benefits of certain other rehief provisions available under the Code. At the present time, the only elections that are statutorily incompatible with mcome averaging are the elections under section 911(a) to exclude foreign earned income and housing allowances, ${ }^{47}$ and the election under section 931(a) to exclude income earned in a United States possession other than Puerto Rico, Guam, or the Virgm Islands. ${ }^{48}$ The bar on using income averaging if the benefits of sections 911 or 931 are claimed has been a part of the income averaging provisions since their mception; 49 the legislative history suggests that the bar reflects primarily a concern with veriflcation of either income fluctuation or the existence of tax penalties associated with that fluctuation. ${ }^{50}$

aging provisions indicates that Congress felt that exclusion of nonresident ahens from the ambit of incoine averaging was important because an individual's averagable income "inust have been subject to tax by the United States throughout the entire base period as well as the computation year." S. Rep. No. 830, 88th Cong., 2d Sess. 144, reprinted in 1964 U.S. CODE CONG. \& AD. News 1673,1818 . Income averaging is premised on the notion that taxpaycrs are penalized by the unfortunate effect of applying progressive rates to fluctuating incomes. Id. at 140, reprinted in 1964 U.S. CODE CONG. \& AD. NEws at 1814. Because nonresident aliens are not required to declare their worldwide income on their U.S. tax returns, I.R.C. $§ 872$ (a) (1982), the IRS is in no position to verify either that the taxpayer's total income has fluctuated or that any tax penalty is associated with such fluctuation. While it is possible to imagine standards under which the taxpayer could be allowed to prove that a tax penalty had been exacted, such provisions would surely be very complicated. Congress apparently views the relief provided by incone averaging as a inatter of legislative grace, which it has chosen not to extend to nonresident aliens.

47. See I.R.C. $\S \S 911$ (a), 1304(b)(1) (1982).

48. I.R.C. $\S 1304(b)(2)$ (1982) makes all of the benefits of subpart D, I.R.C. $\$ \$ 931-936$ (1982), inapplicable to taxpayers who elect to use income averaging. Technically, the qualified exclusion of income sourced in a United States possession provided by I.R.C. $\S$ 931(a) (1982) is not a inatter of election; the fact, however, that section 1304(b)(2) makes section 931 inapplicable to taxpayers who elect income averaging ineans that individuals otherwise eligible for both section 931 treatment and income averaging have an essentially free choice between them.

49. See Revenue Act of 1964, Pub. L. No. 88-272, §232, 78 Stat. 19, 108 (codified as amended at I.R.C. $\S \S 1301-1305$ (1982)).

50. This is also the major concern with respect to nonresident alien eligibility, see supra note 46 , but that concern surely has less force when applied to Anerican citizens whose worldwide income is verifiable. The problem was not discussed fully in Congress. See H.R. Rep. No. 749, 88th Cong., 1st Sess. 114, reprinted in 1964 U.S. CODE CONG. \& AD. News 1313, 1423; see also S. REP. No. 830, supra note 46, at 144, reprinted in 1964 U.S. CODE CONG. \& AD. News at 1818.

For tax years between 1969 and 1981, a restriction of much broader signiflcance was the bar on claiming the benefits of both income averaging and the maximum tax on "earned" or "personal service" income under section 1348 of the Code. The maximum tax provisions were added to the Code by the Tax Reform Act of 1969, Pub. L. No. 91-172, §804, 83 Stat. 487, 685-86 (effective for tax years beginning in 1971) (codified at I.R.C. $\$ 1348$ (1976)). These provisions were repealed by the Economic Recovery Tax Act of 1981, Pub. L. No. 97-34, \& 101(c), 95 Stat. 172,183 (effective for tax years beginning in 1982). The terms "earned" or "personal service" incoine applied largely to wages, salaries, and incoine froin self-employment, and were incant to 
3. Taxpayers Having No More Than $\$ 3000$ of Averagable Income. The disqualification of taxpayers having no more than $\$ 3000$ of averagable income is not stated in the "eligibility" portion of the income averaging provisions in section 1303; rather, it is contained in the general description of incoine averaging computation in section 1301. It is worth listing as a limitation on eligibility, however, to reinforce the point that many otherwise eligible individuals who liave incurred a tax penalty as a result of incoine fluctuation will not be allowed to abate any part of that penalty under section 1301 .

The $\$ 3000$ ininimum averagable-income threshold for averaging eligibility is one of the more unfortunate features of the present averaging provisions. First of all, a flat dollar limit operates to exclude many more low-income taxpayers from averaging than it does high-income taxpayers, since a particular percentage incoine fluctuation produces less averagable incoine for the former group than for the latter. ${ }^{51} \mathrm{~A}$ taxpayer with an average base-period income of $\$ 5000$, for example, must experience an eighty percent increase over that level in the com-

distinguish such income from investment income. Originally, the concept was labeled "earned" income. In the Tax Reform Act of 1976, Pub. L. No. 94-455, \& 302, 90 Stat. 1520. 1554-55 (codified at I.R.C. $\& 1348$ (1976) (repealed 1981)), Congress made a number of changes in the maximum tax, one of which was to apply the maximum tax provision to "personal service" income, perhaps in recognition that income from investments could also be said to be "earned" in the natural meaning of that term.

Although the bar on using both the maximum tax and income averaging has been obviated by the former's repeal, it nevertheless provides an interesting example of the willingness of Congress to sacrifice fairness at the altar of simplicity, at least in the Tax Reform Act of 1969. It is certainly possible to imagine a method of combining the maximum tax and income-averaging provisions. Because, in effect, the averagable income is sliced into five parts, and taxed as though received in five equal portions in the four-year base period and the computation year, it would only be necessary to subdivide the averagable income into a personal-service amount and a nonpersonal-service amount, topping off the rates at the $50 \%$ maximum for the former but not for the latter.

In amending the averaging provisions, however, Congress in the 1969 Tax Reform Act had already gone some distance in the direction of genuine simplification. In the interest of simplicity, it took at least a mild political risk of appearing to favor gamblers and scions of the rich by allowing - contrary to the Revenue Act of 1964-averaging of gambling income, and income from gifts. Tax Reform Act of 1969, Pub. L. No. 91-172, $\S 311,83$ Stat. 487, 586-88 (codified at I.R.C. $\S 1302$ (1982)). This made averaging simpler by making it unnecessary to adjust each of the five years' income to take out gambling income and income from gifts before performing the actual averaging computation. Adding a new subsection-and implicitly creating a new form, or complicating an existing one-to allow simultaneous maximum tax/income-averaging computations was not something Congress was willing to do. It made no claim that a simultaneous computation would be excessively favorable; it said only that it would be too complex. See H.R. REP. No. 413, 9lst Cong., lst Sess. 209, reprinted in 1969 U.S. CODE CONG. \& AD. News 1645, 1731-33.

51. See infra note 194 and accompanying text for a discussion of the vertical equity problem created by the $\$ 3000$ threshold. 
putation year in order to have inore than $\$ 3000$ of averagable income..$^{52}$ In contrast, a taxpayer with an average base-period income of $\$ 50,000$ needs only a twenty-six percent increase over that level in the computation year in order to have more than $\$ 3000$ of averagable income. ${ }^{53}$ Thus, over the course of a five-year period, a person earning $\$ 50,000$ each year may find that he needs hittle more than an annual cost-ofliving increase to make him eligible for averaging; the lower-income taxpayer will rarely find that inflation by itself produces a sufficient percentage fluctuation to permit averaging. ${ }^{54}$

4. Individuals Receiving Substantial Support From Others. The general rule of the support test, expressed in section 1303(c)(1) of the Code, is that an individual is disqualifled from income averaging if he or his spouse provided less than half of his support during any of the four base-period years. ${ }^{55}$ Congress's stated concern in the support test

52. $(\$ 5000 \times 120 \%)+\$ 3001=\$ 9001$, which is $80 \%$ more than the $\$ 5000$ average base-period income.

53. $(\$ 50,000 \times 120 \%)+\$ 3001=\$ 63,001$, which is only $26 \%$ nore than the $\$ 50,000$ average base-period income. Obviously, because average base-period income is multiplied by $120 \%$ to determine unaveragable income, the minimum fluctuation necessary to be eligible for averaging approaches a limit of $20 \%$.

54. See infra notes 116-38 and accompanying text for a discussion of inflation-induced averaging. The $\$ 3000$ threshold also exacerbates the erratic nature of the relief available under incoine averaging, even to the point of introducing a peculiar discontinuity into the income tax structure. This is most pronounced at lower income levels and can best be illustrated by an example. Imagine a married taxpayer with only $\$ 2500$ of taxable income in each of four consecutive years. If he earns $\$ 6000$ in the fifth year, he will be ineligible for averaging, because he has only $\$ 3000$ of averagable income. $(\$ 6,000-(\$ 10,000 \times 30 \%)=\$ 3000)$. He will incur a tax of $\$ 291$, based on the rate schedules of I.R.C. $\S 1(\mathfrak{a})(3)$, all of which is a fluctuation penalty, because his five-year income of $\$ 16,000$ if evenly distributed over the period, would all have been within the zero bracket. While not an enormous sum, this $\$ 291$ is by no means insignificant, especially in light of the taxpayer's economic circumstances.

If the taxpayer earns $\$ 6001$ in the fifth year, however, he will have $\$ 3001$ of averagable incoine, and will be able to save $\$ 181$ of the $\$ 291$ of tentative tax by electing income averaging. That a single additional dollar of taxable income in the computation year actually reduces tax by $\$ 181$ seems highly undesirable. It is also unnecessary. See infra notes 303-20 and accompanying text for a description of a proposed computational mechanism that is free of irregularities of this sort.

55. I.R.C. $\S 1303(c)(1)$ (1982). This disqualiflcation is subject to a number of exceptions, each of which has the effect of re-qualifying certain taxpayers who would otherwise be disqualified by the 50\% rule. The "nonstudent" exception provides that a taxpayer who has reached the age of 25 , and has not been a full-time student during at least four tax years after his twenty-first birthday inay elect income averaging without having satisfied the self-support requirement. I.R.C. $\S 1303(\mathrm{c})(2)(\mathrm{A})(1982)$.

The "major accomplishment" exception provides that a taxpayer may eleet income averaging despite failure to satisfy the self-support requirement if more than half his income in the computation year is attributable to work performed by him in substantial part during two or more of the base-period years. I.R.C. $\& 1303$ (c)(2)(B) (1982). This provision reflects Congress's effort to requalify young authors, painters, and the like, who may have been supported during the years in 
was that the averaging taxpayer "be a member of the labor force in both the computation year and in the four base period years." 56 The committee reports do not elaborate on why this was thought to be important, but it seems likely that the primary consideration was to preclude newly emancipated young adults during their first few years of employment from the virtually autornatic qualification for averaging that would otherwise result from their very-low-income or no-income years during which they were supported by their parents. This, in turn, must reflect the view that the low reported incomes in the base periods of newly emancipated young adults are not truly representative of their economic situations. ${ }^{57}$

which a major opus was produced, but who were, nevertheless, in the work force in soine sense during those years. This exception has sparked several colorful cases. See, e.g., Wilson v. United States, 322 F. Supp. 830, 832 (D. Kan. 1971) (Miss America title, which could perhaps be attributed to prelimmary work, did not produce taxpayer's 1965 and 1966 income, but oniy provided her with the opportunity to earn income); Heidel v. Coinmissioner, 56 T.C. 95, 106 (197I) (bonus paid to taxpayer upon signing a professional football contract not paid for college "work," but for prospective work for the professional team).

The third exception addresses difficulties arising from the interrelationships of joint tax returns and the eligibility of each spouse to average income. A married taxpayer otherwise eligible for income averaging inay elect to average his income on a separate return regardless of whetler his spouse is also eligible for averaging. I.R.C. $\S \S 1302$ (b)(3)(C), 1304(c)(2) (1982) (explicitly referring to averaging by married individuals filing separately). Conversely, if a joint return is filed, both individuals must be ehigible for averaging if the tax of the joint return is to be computed using the inconne-averaging provisions. Treas. Reg. § 1.1303-1(a) (1983). Congress, recognizing that this would often unfairly force taxpayers to choose between the benefits of averaging and the benefits of filing joint returns, promulgated the "supported spouse" exception. This exception provides that an individual will be an "eligible individual" for income-averaging purposes despite having been supported during the base period if the individual's income in the computation year is no more than $25 \%$ of the adjusted gross income shown on a joint return. I.R.C. $\S 1303$ (c)(2)(C) (1982).

56. H. R. REP. No. 749, 88th Cong., Ist Sess. 114 (1964), reprinted in 1964 U.S. CODE CoNG. \& AD. NEws 1313, 1421. Although Congress claimed to be concerned with labor market participation, it did not premise eligibility for averaging precisely on that criterion. Rather, it made selfsupport-whether from the sweat of the taxpayer's brow or the dividends from his stock-the test. I.R.C. $\$ 1303$ (c) (1982).

57. Conceptually, this is far from satisfying. To disregard a former student's low- or zeroincome ligh school years because of his parents' support is, in some sense, to treat him as though he were receiving part of his parents' income. Yet, beyond the $\$ 1000$ exemption allowed for his support, his parents are allowed no income-shifting advantage to reflect the view that soine significant part of their income was devoted to the support of their son.

There may be, however, a more satisfactory justification for denying the benefits of averaging to newly emancipated adults. As suggested above in the discussion of the computation mcchanics, income averaging is, and should be, designed to relieve only the effects of unusual fluctuations in income. Because most people who carn income do have a discrete point at which they first enter the labor market, it may make sense from a tax policy viewpoint to try to achieve lorizontal equity by withholding income-averaging relief from all such entrants rather than by granting relief to all. This is perhaps analogous to low our tax law treats cominuting expenses; they seem clearly to be costs of earning a living, but because nearly everyone incurs them, it is easier froin an 


\section{Policy Analysis of Income Averaging}

\section{A. Introduction.}

The preceding sections were intended to provide an understanding of the mechamics and availability of the federal incoine averaging provisions. This section focuses more directly on the policy issues underlying incoine averaging.

The soundness of a tax system can be evaluated under a number of criteria. $^{58}$ Although the criteria take slightly different shapes in different hands, there is general agreement that fairness, efficiency, adininistrability, economic stabilization, growth, ${ }^{59}$ and, of course, the raising of revenue, are the primary goals in the design of a tax. ${ }^{60}$

admimistrative view, and equally fair, to ignore them. See M. Chirelstein, Federal Income TAXATION 92 (3rd ed. 1982).

This is not wholly convincing; even if everyone experiences an entry into the labor market, it does not follow that all taxpayers incur the same fluctuation penalty. Some individuals may experience fairly gradual moveinent from no income to a substantial incoune. An automobile mechanic inay enter the labor force as a trainee at about the ininimuin wage, and steadily but modestly mcrease his earnings as his skill mcreases with experience. Such an individual's fluctuation peualty between the ages of 18 and 30 will be small relative to that of an individual who has little or no imcome during four years of college and three years of law school, and then takes a job as an associate in a New York City law firm.

The imequity of denying averaging to both the mechanic and law-firm associate during the first four years of their self-support could be more easily defended if it did indeed result in administrative savings, as does the disallowance of commuting expense deductions. The net administrative savings inay be modest, however, because the support test is itself complex and difficult to administer. There has been a substantial amount of litigation and ruling activity over the basic support test itself. See, e.g., Sharvy v. Commissioner, 566 F.2d 1118 (9th Cir. 1977); Jolitz v. Commissioner, 73 T.C. 732 (1980); Dykstra v. Commissioner, 4 T.C.M. (CCH) 890 (1982); Wyche v. Commissioner, 38 T.C.M. (CCH) 926 (1979) (cases dealing with the issue of whether the taxpayer had provided at least one-half of his support during the years over which he averaged his income). See also infra note 83 and accompanying text for a discussion of administrability.

58. There are about as many lists of criteria as there have been tax policy commentators. See, e.g., R. Musgrave \& P. Musgrave, Public Finance in Theory and Practice 235 (3d ed. 1980) [hereinafter cited as Musgrave \& MusGrave]; J. Pechman, Federal Tax Policy 5 (4th ed. 1983); Sneed, The Criteria of Federal Income Tax Policy, 17 Stan. L. Rev. 567,567 (1965).

59. The "stabilization" and "growtl" criteria may seem at first to be contradictory. However, the stabilization criterion reflects a bias against irregularity, not a bias against steady growth.

60. Pechman coinpresses this list into three coinpound factors. J. PECHMAN, supra note 58, at 5. Musgrave and Musgrave use this list, but split administrability into a fairness component and a cost component, while combining stabilization and growth imto a single factor. MUSGRAve \& MUSGRAVE, supra note 58, at 235. Sneed's criteria have a spaciousness of presentation that makes it difficult to compare them with any list that uses single words or short phrases to describe each criterion. See Sneed, supra note 58, at 567. Nevertheless, 1 think his goals substantially correspond to those in the text.

Some commentators use other standards to appraise a tax as well, but the additional factors generally may be considered derivative from the six goals listed. The goal of making the tax "understandable to the taxpayer," MusGrave \& MusGrave, supra note 58, at 235, could be derived from the fairness and administrability criteria. The goal of designing a tax to reduce inequities, H. Groves, Post War Taxation and Economic Progress, $373-74$ (1946), is more 
Although they are usually set out as criteria for evaluating a "tax"-for example, the federal income tax - they can be used as well to evaluate the degree to which any part of an overall tax structure aids or impedes achievement of those objectives. Care must be taken when this is done, however, because the soundness of the overall tax is not a simple sum of the strengths and weaknesses of each part, weighed separately under each criterion. An unfavorable feature of one part of a tax system may be in such perfect equipoise with some other part of the system as to produce a result that is more favorable overall than any system mcorporating improvements to the feature. ${ }^{61}$ This is nothing but another application of the familiar "second-best" paradox. ${ }^{62}$

It appears, however, that income averaging poses no serious second-best problems. It further appears that incoine averaging has relatively little impact on the achieveinent of most of the standard taxpolicy goals. Rather, income averaging must rise or fall almost entirely on the basis of how well it satisfies the goal of fairness. The first part of this section will provide a brief analysis of income averaging in terms of what may be called the "pragmatic" 63 criteria: efficiency, adininistrability, stabilization, growth, and revenue-raising, in order to show that achievement of these goals is little affected by the presence or absence of income averaging. Indeed, if anything, this analysis suggests that the few discernible effects of averaging are more likely to be unfavorable than favorable.

After discussing those elements of policy analysis that appear to be less central to a discussion of income averaging, the second part of this

problematic. If one's notions of fairness include reduction of inequality, then the six factors in the text subsume this factor; if one does not believe that inequality is unfair, one is likely to reject reduction of inequahty as a criterion of a sound tax. In either event, the six-factor list in the text is not incomplete.

61. See, e.g., Bittker, A "Comprehensive Tax Base" as a Goal of Income Tax Reform, 80 HARV. L. REV, 925, 984 (1967) (continued exclusion of unemployment compensation and social security benefits may equalize tax burden if gifts, bequests, and imputed income from personal property are also excluded).

62. See Lipsey \& Lancaster, The General Theory of Second Best, 24 REv. Econ. Stud. 11 (1956). As applied to the federal income tax, the second-best paradox would suggest that if some departures from the "best" tax system are necessary for admmistrative or other reasons, the nextbest tax system may not be the one whose individual features most closely resemble the features of the best system. Rather, the second-best system may include some features that depart considerably from their counterparts in an ideal system, but are balanced with other features in such a way that the overall burden distribution of the second-best tax resembles the burden distribution of the ideal tax more closely than any alternative tax systems, including those whose individual features seem more appealing. See Bittker, supra note 61, at 984.

63. The term "pragmatic" is used here mostly as a matter of convenience to distinguish fairness concerns from all other tax policy goals. The term seems reasonably apt: A perfect tax system would be one that was, above all, perfectly fair; deviations from perfect fairness reflect primarily considerations of practicality, or if you will, pragmatism. 
section considers averaging in light of the fairness criterion. This part concludes that the unfairness of a tax system without averaging is exaggerated, and that what little unfairness exists is only sporadically relieved by income averaging. As a consequence, the case for outright repeal, or at least drastic curtailment, of averaging seems strong indeed.

\section{B. The "Pragmatic" Tax Policy Criteria.}

1. Efficiency. A tax system's impact on the efficiency of private inarkets is almost invariably a negative one. ${ }^{64}$ The underlying assumption is that markets are efficient in allocating goods and services to their higlest and best uses, and that the tax system, by altering the parameters of the decisions made by firms and households, introduces distortions from the most efficient allocation of resources. ${ }^{65}$ The efficiency goal, then, is to minimize the nearly inevitable distortions caused by the tax; efficiency is produced passively-in fact, it is not so much produced as it is permitted by a good tax.66

Efficiency concerns do not seem to be heavily implicated in the income averaging issue. Admittedly, one can imagine that the specter of a fluctuation penalty may affect some small number of taxpayer decisions. The general form of decisions that may be affected by a fluctuation penalty would involve choices between an economic activity that produces a steady mcome stream and an alternative activity that produces an income stream of larger present value, but of lesser regularity. The latter activity would presumably be chosen in a tax-free world, ${ }^{67}$ but may not be cliosen if the irregular incoine streain is burdened by a fluctuation penalty that is greater than the difference in present value between the two imcome streams. Thus, it would not be unreasonable to suppose that fluctuation penalties might make people somewhat less willing, for example, to buy lottery tickets or to embark on careers as novelists.

64. It is theoretically possible to design a tax that is highly efficient by choosing a base that is wholly unconnected to any particular economic activity. A head tax assessed against all citizens would be an example. The defects of a head tax are obvious, however, and once the tax system selects income, consumption, land, or whatever, as a base, it begins to distort economic decisions.

65. See MusGrave \& Musgrave, supra note 58, at 303-17.

66. Some public finance theorists consider the minimization of administrative and compliance costs to be also an aspect of the efficicncy of a tax, but it seems more natural to evaluate those nnder the adininistrability criterion. Musgrave and Musgrave employ this latter approach. Id. at 302-03.

67. For this to be true as a general matter, it must also be assumed that credit markets are efficient, so that the taxpayer's consumption pattern is not impinged by the irregularity of his income under the latter option. It should be further assumed that the individual choosing among alternative income streams is risk-neutral, because it seems likely that the regularity of an income flow is associated with the certainty of that flow. 
Facilitation of lotteries and gambling has, of course, never been the policy of the federal government. Permitting novelists to flourish comports better with public pohcy, but anecdotal evidence suggests that large numbers of young adults are entirely prepared to make substantial sacrifices to pursue careers in writing, dancing, singing, paimting, professional sports, and other activities characterized by fluctuating incomes. 68 It seems very doubtful that the existence of a fluctuation penalty would much impede this zeal; nor does it appear that supporters of averaging have placed any significant reliance on the argument that fluctuation penalties misallocate resources away from activities of the sort histed above. ${ }^{69}$

A somewhat more serious allocational issue is raised by the possibility that fluctuation penalties may discourage risk-taking generally. It is likely that uncertainty in the flow of income is correlated with irregularity in the flow of income; acceptance of uncertainty in the flow of income is a definitional characteristic of risk-taking, which is an essential part of economic innovation. ${ }^{70}$ By this string of connections,

68. My evidence may be anecdotal, but the anecdotes are very widespread: Opera singers, athletes, and the hike are frequently cited as examples of professions in which the supply of labor is quite inelastic. When labor supply is inelastic, tax burdens create less distortion. See, e.g., MUSGRAVE \& MUSGRAVE, supra note 58, at 322 (which suggests that imposing heavier taxes on opera stars than on other workers may be relatively efficient, by reason of the opera stars' presumed inelasticity of labor supply).

69. It is possible to find glimmerings of an allocational argument in soine of the inaterials prepared prior to the 1964 enactinent of general income averaging, but I am not aware of any fully developed argument to this effect. An example that comes as close as any to an allocational argument is the following excerpt from Becker, An Averaging Proposal, in TAx Revision CoMPENDIUM, supra note 6, at 675, 677:

The fact that [averaging] would materially aid a great seginent of those in artistic pursuits calls to mind an important corollary benefit to be derived. I refer to the growing realization that our Government can no longer afford the luxury of ignoring the welfare of America's creators of culture .... [T] tion to make a life devoted to the arts more appealing and rewarding . . . . In this vast competition between cultures we cannot overlook any means which will aid the continuing growth in quantity and quality of America's artistic endeavors.

In particular, the suggestion that the quantity of artistic endeavors would be affected by averaging is an allocational argument, albeit an informal and unsupported one. Because the extent of misallocation caused by a tax is directly related to the elasticity of the burdened commodity, see MusGRAVE \& MUSGRAVE, note 58, at 305-06, it can be inferred that the misallocation that would be caused by fluctuation penahtes would be modest.

70. See P. SAmuelson, Economics 621-23 (10th ed. 1976); see generally, W. Blum \& H. Kalven, The Uneasy Case for Progressive Taxation (1970); F. KNight, Risk, UnCerTAINTY AND PROFIT (1921). The debate over the effects of progressive taxes generally on willingness to take risks has broken out again recently in the pages of the National Tax Journal. Fellingham and Wolfson have inodeled the traditional position that progressive taxes will induce risk-neutral taxpayers to accept less risk. See Fellingham \& Wolfson, The Effects of Alternative Income Tax Structures on Risk-Taking in Capital Markets, 31 NAT'L TAX J. 339 (1978). Schneider replied with a model suggesting that risk-neutral taxpayers could, under some circuinstances, reinain neutral even under a progressive tax. See Sclineider, The Effects of Progressive and Propor- 
penalties imposed on irregular income flows could arguably depress innovation.

The possibility that this may be so cannot be conclusively rejected. It should be remembered, however, that too much risk-taking is as undesirable as too little; again, the efficiency criterion calls for as little interference with the market as possible. There are several features of the federal income tax, in addition to averaging, that limit the problem of fluctuation penalties, and at least a few provisions that explicitly encourage risk-taking.

It should also be noted that the concern here is with busmess risktaking, and about three-quarters of American business activity, as measured by its contribution to national income, is undertaken by corporations. ${ }^{71}$ Although there is some graduation in the corporate tax rates at the lowest end, ${ }^{72}$ the corporate income tax is not intended to operate as a progressive tax..$^{73}$ The rates flatten at forty-six percent for annual corporate income in excess of $\$ 100,000 ; 74$ the lower rates applying to the first $\$ 100,000$ of income are intended inerely as a relief measure to small businesses..$^{75}$ Thus, there is little or no fluctuation penalty associated with variability of corporate income, and, of course, no averaging device available for what variation there is. Corporations do distribute

tional Income Taxation on Risk-Taking, 33 NAT'L TAX J. 67 (1980). However, the range of outcomes in Schneider's progressive tax model involve movements within a single marginal tax bracket. That is, he examines a tax structure in which an income of $\$ 20,000$ is taxed at an average rate of $20 \%$, an mcome of $\$ 50,000$ is taxed at an average rate of $40 \%$, and an income of $\$ 80,000$ is taxed at an average rate of $45 \%$. That structure meets the definitional requirements of a progressive tax, but it can be seen that moving from an income of $\$ 20,000$ to $\$ 50,000$ causes a tax increase of $\$ 16,000$, or $53.3 \%$ of the income gain, and that moving from an income of $\$ 50,000$ to $\$ 80,000$ also involves a tax increase of $\$ 16,000$, and the same rate of $53.3 \%$ of the income gain. Thus, shifting outcomes from the two extremes to the mean involves no fluctuation penalty. Only in this very special case, it appears, would neutrality be preserved. See also Fellingham \& Wolfson, Progressive Income Taxes and the Demand for Risky Assets, 37 NAT'L TAX J. 127 (1984).

71. In 1981, about $\$ 1.9$ trillion of national income originated in business activities, of which about \$1.44 trillion origmated in corporate businesses. BUREAU OF THE CENSUS, STATISTICAL ABSTRACT OF THE UNITEd States, 1982-83, 423 (Table 700) [hereinafter cited as StatisticaL ABSTRACT, 1982-83].

72. I.R.C. $\S 11$ (b) (1982) specifies the following tax rates for corporations: 15\% for income not in excess of $\$ 25,000$; $18 \%$ for imcome between $\$ 25,000$ and $\$ 50,000 ; 30 \%$ for income between $\$ 50,000$ and $\$ 75,000 ; 40 \%$ for income between $\$ 75,000$ and $\$ 100,000$; and $46 \%$ for income in excess of $\$ 100,000$. These rates apply to corporations generally, but there are exceptions for life insurance companies, real estate investment trusts, mutual funds, and electing small-busimess corporations. See I.R.C. $\S \S 11$ (c), 1363(d) (1982).

73. Musgrave \& Musgrave, supra note 58, at 420; J. Pechman, supra note 58, at 134.

74. I.R.C. $\$ 11($ b) (1982). About $84 \%$ of all corporate income is exposed to this top rate. Author's estimate based on data in INTERNAL Revenue SERvice, STATISTICS OF INCOME - 1980, CORPORATE INCOME TAX RetURNS 67 (Table 17, cols. 1, 2) (1981).

75. Musgrave \& MUSGRave, supra note 58, at 420-21. 
some of their profits in the form of dividends to individuals, ${ }^{76}$ but this flow is determined by the directors. That flow can be, and typically is, managed so as to minimize year-to-year fluctuations. ${ }^{77}$ Thus, although income averaging may make some modest contribution to the overall efficiency of the tax system, both the magnitude and the scope of these effects appear to be quite limited.

2. Administrability. By its very nature, any averaging device involves multiyear accounting in one forn or another. This is inevitably troublesome in a tax systein whose rules are otherwise organized on the basis of an annual accounting requirement. While the law is quite clear concerning permissible choices as to filing status, ${ }^{78}$ determination of marital status, ${ }^{79}$ and apphicability of any particular rate structure, ${ }^{80}$ all these concepts have to be redefined to deal with a multiyear incomeaveraging formula.

Despite this rather considerable potential for problems, however, it must be conceded that the income-averaging mechanism presently in place does not appear to have imposed significant difficulties of administration on the tax system. This can best be seen if the administrability criterion is broken down into its constituent elements. Although there is some overlap ainong such eleinents, a listing nevertheless provides a

76. About $\$ 63$ billion in corporate profits were distributed to individuals in 1981 . This amount represented about $42 \%$ of corporate after-tax profits. STATistical ABSTRACT, 1982-83, supra note 71 , at 423,425 (Tables 699,703 ).

77. Even as to individuals, there are a number of devices available that mitigate the bunching of business or investment income. The principal example in this regard is the very favorable treatment of capital gains. Gains on investments in capital assets, see I.R.C. $\S 1221$ (1982), are not taxed at all until the asset has been sold or exchanged, I.R.C. $\S 1001$ (c) (1982), and are taxed at the latter point at a rate that is typically only $40 \%$ as high as the owner's normal marginal rate. I.R.C. $\$ 1202$ (1982) permits a taxpayer to deduct $60 \%$ of net gains on capital assets held for more than one year, which assures that, in the normal case, the tax burden on such gains will be no higher than $40 \%$ of the tax burden on other marginal income items received by the taxpayer.

It should also be noted that Congress has available tools much more powerful than income averaging to influence the level of risk-taking and innovation in the economy. Special credits for research and development, see I.R.C. $\$ 44(\mathrm{f})$ (1982), and a generally favorable treatment of investments in physical capital, see I.R.C. $\$ 168$ (1982), are among the tools that Congress has chosen in recent years to encourage capital investment. See also Johnson, Tax Shelter Gain: The Mismatch of Debt and Supply Side Deprcciation, 61 TEx. L. Rev. 1013 (1983); Warren \& Auerbach, Tax Policy and Equipment Leasing After TEFRA, 96 HARV. L. REv. 1579 (1983); Warren \& Auerbach, Transferability of Tax Incentives and the Fiction of Safe Harbor Leasing, 95 HARv. L. REV. 1752, 1753-58 (1982).

78. I.R.C. $\S 2(b)(2)-(3)(1982)$.

79. I.R.C. $\S 143$ (1982); but see Boyter v. Commissioner, 668 F.2d 1382, 1387 (4th Cir. 1981) (sham transaction doctrine may be applied to determine whether purpose of divorce was to escape taxation at joint rates).

80. I.R.C. $\S 1$ (1982) contains three sets of tables, for tax years beginning in 1982, in 1983, and after 1983 , respectively. 
useful framework for analysis. ${ }^{81}$ The first element is the direct administration costs: the governmental costs of developing, processing, and auditing income averagimg schedules. The second element involves the private costs of compliance. The last element is not truly an imdependent element, but ratler influences the first two; it relates to the complexity and clarity of the legal concepts. A few comments about each of these will be sufficient to show that the averaging mechanism does not create serious problems in the area of administrability, although it has some significant compliance costs.

a. Administration. Administration of income averaging is quite simple and straightforward from the viewpoint of the Internal Revenue Service (IRS) for two principal reasons. First, in the majority of cases averaging is entirely mecliamcal. Few cliaracterizations or judgments of any kind need be made. No business/pleasure, capital/ordinary, or other fine lines need be drawn. There are a fairly significant number of computations in income averaging, but these are readily automated. The second factor making the task of the IRS simple is that the computation is, $\mathrm{m}$ most cases, ${ }^{82}$ based solely on numbers that have appeared on the Form 1040. Thus, no additional documentation is required beyond that which the taxpayer has otherwise been compelled to provide. The bulk of averaging scliedules require little or no processing or auditing effort on the part of the IRS. ${ }^{83}$

b. Compliance. The comphance costs of income averaging-the private costs of data collection and reporting incurred by taxpayersare somewhat more problematic. The data collection aspects of the income-averaging task are simpler than they are in many areas of tax reporting. Compared with the compiling of dozens of receipts for medical expenses, charitable contributions, interest payments, and other de-

81. Musgrave and Musgrave do not list these factors in precisely the way that 1 have here, but all of these factors are mentioned in their discussion of administrability. See MusGrave \& MusGRAVE, supra note 58 , at $235,302-03$.

82. Where marital status has changed, it may be necessary in some cases to segregate the parties' respective incomes, something which, if joint returns were filed in previous years, may never have been reflected on any Form 1040. See supra note 55.

83. The audit effort required in nonroutine cases may, of course, be soinewhat higher. For younger taxpayers, verifying that the self-support requirement, I.R.C. $\$ 1303$ (c) (1982), has been satisfied may sometimes be troublesome. And, as mentioned in the preceding note, verifying the separate incomes of averagers whose marital or filing status has changed, see I.R.C. $\$ 1304$ (c) (1982), inay present some audit problems. Even in these cases, however, the necessary facts are subject to reasonably good documentation. It would thus appear that even the special cases in the averaging area present no greater audit difficulties than the normal cases in, for example, the area of business travel that has substantial personal benefits. On the whole, then, averaging does not seem particularly difficult for the IRS to adininister. 
ductible expenses needed to complete a Schedule $\mathrm{A},{ }^{84}$ or the collection of Form 1099 copies needed to complete Schedule $B,{ }^{85}$ the averaging computation data requirements are slender. One must locate only four documents: the Form 1040 copies for each of the base years. ${ }^{86}$

Though data collection may not be troublesome, using the averaging mechanism is. To taxpayers, the computational framework of the income averaging form-Schedule G-may be the most magical and intimidating of any in the federal tax system. On the thirty-two lines of the schedule, ${ }^{87}$ the taxpayer is called upon to enter or reenter data at no fewer than twelve points ${ }^{88}$ and is required to perform a minimum of twenty-four arithmetic operations with respect to those data entries. ${ }^{89}$ At the conclusion of this process, the now-dazed taxpayer produces a

84. Schedule A is used to report a taxpayer's itemized deductions, including medical and dental expenses, deductible taxes, interest paid, charitable contributions, casualty and theft losses, and miscellaneous deductions, such as professional expenses and investment expenses.

85. Schedule B is used to report a taxpayer's interest and dividend income, and inust be filed if the amount received in either category totals more than $\$ 400$. See IRS Forn 1040, Schedule B; Treas. Reg. $\& 1.6012-1(\mathrm{a})(6)$ (1983). Form 1099 is used by payors of interest and dividends to report payments of $\$ 10$ or more to individual taxpayers. See Treas. Reg. $\$ 1.6042-29$ (1983). Copies of these forms must be provided to the taxpayers in question. See I.R.C. $\$ \S 6042$ (c), 6049(c) (1982).

86. This is true, of course, only where filing status has not changed, and the taxpayer, if married, remains married to the same spouse throughout the computation period. The data-gathering process can become quite complex if a joint return was filed in one of the base years, and a separate or single return was filed in the coinputation year, because incoine aggregated on such a joint return will have to be disaggregated for the averaging computation, a process that will usually require resort to documents other than the Form I040. Of course, even as to the simple case where filing status has not changed, it should be recognized that the filing talents of taxpayers vary widely; one presunes that finding tax return copies for four prior years is very easy for some households and completely impossible for others. And, though the number of documents needed is small, the fact that the documents range in age up to four years, and are likely to be stored in four different places, complicates the data collection. The IRS will provide a taxpayer with copies of his prior returns, but its response to requests for such data may be tortuously slow, especially durimg the period just prior to the April 15 filing deadline when a would-be income averager is most likely to make such a request. Thus, for taxpayers who need the Service's help in collecting their data, income averaging will often entail the additional burden of seeking an extension of filing time, or the filing of an amended return. See I.R.C. \& 1304(a) (1982) (allowing a taxpayer to elect income averagimg with respect to a computation year "at any tine before the expiration of the period prescribed for making a claim of refund . . . for the taxable year").

87. The number of lines varies inodestly from year to year, depending primarily on what adjustments inust be made to achieve comparability between the base years and the computation year. The material infra notes $88-90$ and accompanying text is based on the 1983 Schedule G.

88. Lines $1,2,4,5,7,8,9$, and 12 require data entry. Lines 17,20 , and 22 call for the reentry of certain data appearing elsewhere on the schedule.

89. Lines $2,3,5,6,10,11,14,16,18,19,21,23,27,28$, and 32 all require soine computation. Lines 24-26 require that tax liabilities be computed for particular amounts of taxable income. These lines are counted thrice in the total of twenty-four computations because computing a tax hability requires three arithmetic operations: (1) taxable income less the lower bound of the applicable bracket; (2) that result times the applicable marginal rate; and (3) that result plus the tax on all lower brackets. 
number representing his tax habihity,90 which is likely to be about six hundred dollars below what his tax liability would be without averaging.91 The sheer number of data entries and coinputational operations makes it highly probable that taxpayers: (a) will make mistakes; (b) will be intimidated by the averaging schedule; and (c) will have no sense of the significance of each step in the process.

Of course, these facts, together with the magical savings of several hundreds of dollars of tax per eligible taxpayer, make income averaging a great boon to the tax return preparation imdustry. Indeed, that imdustry may be the principal beneficiary of the averaging provisions. Like the IRS, major tax-return preparers handle large numbers of averaging computations each year-presumably enough to wholly or partly automate the averaging computation model. ${ }^{92}$ Once the data are entered into an automated process, a completed Schedule $G$ may be only microseconds away. For all the reasons that the IRS finds averaging relatively easy to admmister, one presumes that the major tax preparation services find income-averaging preparation handsomely profitable. Data are not available on the number of Schedule G's which are prepared by professional tax preparers. However, the overall proportion of return preparation done by professionals is about fifty percent. ${ }^{93}$ Assuming that taxpayers are charged approximately twenty-five dollars for preparation of a Schedule $G,{ }^{94}$ it seems reasonable to conclude that the compliance costs of averaging are well im excess of $\$ 100$ million per year. ${ }^{95}$

90. For 1983, the entry from line 32 of Schedule $G$ was to be entered on line 38 of form 1040 , which is captioned simply: "Tax." An irresistable-although somewhat oversimplified-observation is that it takes nearly as many lines to undertake income averaging as it does to do all the other things necessary to compute the tentative tax liability.

91. Individual savings from income averaging averaged $\$ 578$ in 1981 . STATISTICS or $1 \mathrm{~N}-$ COME, supra note 10, at 74 (Table 3.1, col. 18).

92. See, e.g., the income-averaging capabilities of the following computer software: SOFTAX by Design Trends Ltd.; Quick Tax by QuickTax Ltd.; Cal-Q-Tax by Tax Management, Inc.

93. Oversight Hearings into the Operations of the IRS (Tax Assistance Services and Monitoring of Commercial Tax Preparers): Hearing Before a Subcomm. of the House Comm. on Govermment Operations, 94th Cong., lst Sess. 36 (1975) (statement of Donald Alexander, Commissioner of Internal Revenue Service).

94. Although many return preparers charge hourly fees, which makes it difficult to estimate the average cost of Schedule $G$ preparation, at least one preparation service, H \& R Block, charges $\$ 25$ for a simple Schedule $G$, in which marital and filing status have not changed, and all data is provided by the taxpayer.

95. If half of the 6.6 million averagers in 1981 , see supra note 10 , spent $\$ 25$ each on averaging, then over $\$ 82$ million were spent on averaging schedules prepared by professionals. Because of the daunting appearance of the Schedule $G$, it seems reasonable to suppose that more than half of tax returns which included Schedule $G$ were professionally prepared. Also, some accounting should be made for the time consumed by those heroic taxpayers who complete their own Sched- 
In fact, the total may be substantially greater, since there may be a considerable shadow comphance cost. A troublesome fact about the Schedule $G$ is that a taxpayer must compile all the relevant data, and must complete twenty of its thirty-two lines, before he can even determine whether his "averagable incoine" exceeds the $\$ 3000$ ininimum necessary to be eligible for income averaging. Further, some taxpayers who do have more than $\$ 3000$ of averagable income find that, nevertheless, they save no tax by incone averaging. To some degree, intuition may substitute for actual computation, but the opacity of the averaging computation makes rehance on intuition soinewhat treacherous. Presumably, many taxpayers whose incomes have increased modestly do actually coinplete all or a substantial portion of a Schedule G, only to conclude that they are ineligible, and that they have wasted their time.

c. Complexity and clarity of legal concepts. An unfortunately large number of tax issues at any given time present legal quagmires to the taxpayers who inust deal with tlrem. ${ }^{96}$ The present income averaging mechamsm, however, has few legal ambiguities. There are certain averaging issues that spawn disputes, and could be improved by further-probably congressional-clarification. The "major accomplishment" rule is perhaps the inost significant and interesting among these, ${ }^{97}$ though questions relating to documentation of the ainount of income in the base-period years have spawned the greatest volume of hitigation, ${ }^{98}$ largely because taxpayers sometimes have so little incoine in their base-period years that they are exeinpt froin filing requirements, and are consequently careless about recordkeeping.99 As a gen-

ule G's. Taking the latter factor into account, the $\$ 100$ million estimated compliance cost is surely conservative. Of course, it should also be remembered that the cash costs of professional tax return preparation (but not the opportunity costs of self-help) are deductible. I.R.C. § 212(3) (1982). This doesn't reduce the compliance costs, but does shift some of them from private to public accounts.

96. The debt-equity distinction under I.R.C. $\$ 385$ (1982), the includability of fringe benefits under I.R.C. $\S 61$ (1982), and the status of assets sold in the course of business under I.R.C. $\S 1221(1)(1982)$ are a few examples that coine to mind.

97. See supra note 55.

98. See, e.g., McCaskill v. Commissioner, 77 T.C. 689 (1981); Gardner v. Cominissioner, 46 T.C.M. (CCH) 1283 (1983); Brenauer v. Commissioner, 46 T.C.M. (CCH) 784 (1983); Caputo v. Commissioner, 46 T.C.M. (CCH) 521 (1983); Olive v. Commissioner, 45 T.C.M. (CCH) 1249 (I983); Lynch v. Commissioner, 45 T.C.M. (CCH) 1125 (1983); Bianco v. Commissioner, 43 T.C.M. (CCH) 1039 (1982); Venditti v. Commissioner, 42 T.C.M. (CCH) 519 (1981); Kannas v. Commissioner, 40 T.C.M. (CCH) 194 (1980); Hill v. Commissioner, 38 T.C.M. (CCH) 595 (1979); Abernathy v. Commissioner, 37 T.C.M. (CCH) 1529 (1978); Ryza v. Commissioner, 36 T.C.M. (CCH) 269 (1977); Binstein v. Commissioner, 32 T.C.M. (CCH) 450 (1973).

99. See, e.g., Caputo v. Commissioner, 46 T.C.M. (CCH) 521 (1983); Hill v. Commissioner, 38 T.C.M. (CCH) 595 (1979); Binstein v. Commissioner, 32 T.C.M. (CCH) 450 (1973). 
eral matter, however, the income averaging provisions are models of clarity.

Some evidence that this is the case can be gleaned from exainining the judicial and administrative attention that has been formally paid to income averaging. Only forty-nine judicial decisions have been rendered on income averaging in its nearly twenty years of existence. ${ }^{100}$ Only thirteen published administrative rulings and seventeen private letter rulings have been issued with respect to averaging, ${ }^{101}$ and some of these are not genuine interpretations of the averaging provisions, but rather present advice that incoune averaging may be available to mitigate an otherwise harsh result. ${ }^{102}$ Even inore remarkable is that there has not been a revenue ruling issued with respect to the income averaging provisions in nearly a decade. ${ }^{103}$ Given that these provisions are used by six million taxpayers per year, ${ }^{104}$ this paucity of judicial and administrative decisions suggests that Congress succeeded in designing a system that is quite well-defined. ${ }^{105}$

3. Macroeconomic Effects. It cannot be seriously maintamed that income averaging significantly affects the overall characteristics of the income tax with respect to stabilization and growth of the economy.

100. One hesitates to make absolute claims of comprehensiveness as to statistics of this sort. The assertion, however, that there are only 49 cases is based on a search using the Std. Fed. Tax Rptr., the Fed. Taxes Service (P-H), and a Lexis search of all opinions that have used the phrase "income averaging" or have contained citations to any of the relevant code sections. A list of these cases is available froin the author or from this Journal.

101. See supra note 100 .

102. See, e.g., Rev. Rul. 67-350, 1967-2 C.B. 58 (lump-suin "readjustment payment" to an armed forces reservist involuntarily released from active duty is includible in income in the year received, but tax on this income inay be computed using income averaging if taxpayer ineets eligibility requirements).

103. The inost recent was Rev. Rul. 75-324, 1975-2 C.B. 348 (a taxpayer need not use the same accounting method during each year of the base period in order to elect incoine averaging).

104. See supra note 10

105. It is, of course, difficult to make any very scientific analysis of this data. To prove that income averaging is exceptional in its freedom from legal ambiguity one would need to compare the actual volume of cases and rulings with a predicted volume based on some "litigation generation" model that incorporated such variables as the number of taxpayers affected, the tax liability at stake per taxpayer, etc. No such model is presently available.

It would be interesting to experiunent with such a model. One very crude step in that direction was undertaken in connection with the research for this article. The rate of "interpretations" per year for incoine averaging was compared with the rate of "interpretations" of 1.R.C. § 1348 (1982), which, for tax years between 1970 and 1980, capped the marginal tax rates at 50\% for personal-service incoine. The "maxnnum tax," as the latter was called, involved fewer taxpayers and had a lower aggregate tax-dollar effect, although the savings per electing taxpayer was larger. See 1981 STATISTICS OF INCOME, supra note 10, at 73-74 (Table 3.1, cols. 17, 18). It is interesting-but no more than merely interesting-to note that the rate of interpretations was about four times as great for the maximuin tax as for income averaging, even though the maximum tax provisions-like the averaging provisions-seem quite straightforward. 
Averaging has hittle impact on capital formation, and the revenue impact, although appreciable in absolute terms, ${ }^{106}$ has never amounted to as much as . $2 \%$ of the gross national product (GNP). ${ }^{107}$ It will suffice at this poimt to note that income averaging has one modest effect that is adverse to the goal of stabilization and, arguably, one modest effect favoring growth.

a. Stabilization. The well-known stabilization effect of a graduated tax results from its tendency to produce revenue changes that are disproportionate to changes in national income. ${ }^{108}$ Thus, if national income increases $x$ percent, income tax collections will increase by more than $x$ percent. ${ }^{109}$ This is true simply because the increment received by each taxpayer is taxed at his highest marginal rate, which increases the proportion of his total mcome that the income tax accounts for, ${ }^{110}$ and increases the proportion of national income in the aggregate that is devoted to taxes. ${ }^{111}$ Similarly, a decline in national income of $x$ percent would be associated with a revenue loss of greater than $x$ percent, because the lost income would be taken from each taxpayer's highest marginal tax bracket. Thus, a graduated tax stabilizes the economy by withdrawing greater proportional taxes from a growing economy, possibly preventing "overheating," and a lesser proportion from a declining economy, possibly aiding in maintaining family budgets at close to the prior levels. This stabilization theory, of course, is based on the macroeconomic view that consumer demand is the primary engine of the economy, and that the tax system can be useful in preventing consumer demand from growing too rapidly or falling too precipitously. Both premises may be questionable. The stabilization

106. The revenue loss is almost $\$ 4$ billion per year. See supra note 11.

107. The income-averaging savings of $\$ 3,919,414,000$, see supra note 11 , was slightly more than $.1 \%$ of the 1981 GNP for the United States. STATISTICAL ABSTRACT, 1982-83, supra note 71, at 419 (Table 690).

108. See J. Pechman, supra note 58, at 12-13.

109. Pechman estinates that, under the 1981 rate structure, increases or decreases of $10 \%$ in national incoine would produce increases or decreases, respectively, of individual income tax revenues of $15 \%$. Id. at 13 .

110. If indexing of rate brackets under I.R.C. $\$ 1(f)(1982)$ is allowed to take effect in 1985, as the Code presently provides, nominal increases in income might be offset by inflation-induced changes in the rate structure itself. It will continue to be true, however, even in an indexed systein, that real increases in incoine will produce a disproportionately greater increase in tax revenue.

111. It may be worth noting that this is an effect that a graduated tax tends to produce, but it is not a inathematically certain effect. Inagine, for example, an econony of five employed women earning $2 x$ per year, and one unemployed woman earning nothing. If the unemployed woinan gains employment at an income of $x$, national income will rise $10 \%$ from $10 x$ to $11 x$. But if incomes of $2 x$ are taxed at an average rate of $20 \%$, and incomes of $x$ are taxed at an average rate of only $10 \%$, then tax collections will rise only $5 \%$, from $2 x$ to $2.1 x$. 
theory, however, whatever its intrinsic worth, has become firmly entrenched in the established lore of tax policy. ${ }^{112}$

All that need be noted with respect to the role of income averaging in this stabilization effect is that the presence of averaging somewhat dulls the tendency of a graduated tax to exaggerate the revenue-expansion and -contraction effects of national mcome changes. As incomes mcrease, taxpayers will have greater parts of their mcomes exposed to higher rates, but it is also true that a significant number of them will be able to mitigate the effects of those higher rates through averaging. The converse is true as well:113 in a sluggish or decliming economy, fewer taxpayers will be eligible for averaging. Thus, the dampening effect of graduated rates on consumer demand is itself dampened by averaging.

b. Growth. The effect of averaging on growth is simple, and probably very modest. Higl marginal tax rates are thought to depress growth for two reasons. First, they encourage those taxpayers who are exposed to high marginal rates to substitute leisure for labor, ${ }^{114}$ because

112. Pechman adopts this view in its simplest form. J. Pechman, supra note 58, at 12-13. Musgrave and Musgrave present a more sophisticated analysis, but do not seem to qucstion the basic effect. MUSGRAve \& MUSGRAVE, supra note 58, at 616-18.

113. Readers of earlier drafts of this article have found the "converse" effect of income averaging referred to in the text-that is, the tendency of averaging to reduce the dampening effect of a progressive tax in a period of declining national income-to be far from self-evident, perhaps because averaging itself is asymmetrical, lacking as it does a downward averaging device. In fact, the dampening effect referred to is partly the result of this asymmetry, because the absence of downward averaging provisions makes it nearly certain that taxpayers in the aggregate will have fewer dollars of tax savings from averaging in periods of income decline than during periods of growth or normalcy. In contrast, if tax savings from $\S$ averaging were tied to income fluctuations, positive or negative, tax savings from averaging would presumably be high in periods of either growth or decline, and low in periods of stability. These observations, and the general dampening effect explained in the text, can be illustrated by the following example. Assume that the economy in period 1 consists of taxpayers with incomes of $\$ 200$, and that the rate structure imposes a tax of $10 \%$ on the first $\$ 100$ and $30 \%$ on the excess above $\$ 100$. The tax collected will then be $\$ 40$ per taxpayer $((.1 \times 100)+(.3 \times 100))$. If income declines in period 2 by $10 \%$, to $\$ 180$, tax liability will decline by $15 \%$ to $\$ 34((.1 \times 100)+(.3 \times 80))$. This dampens the effect of a recession on disposable income, because after-tax income has declined from $\$ 160$ to $\$ 146$, only an $8.75 \%$ decline, even though pretax income declined a full $10 \%$. This illustrates the basic cushioning effect of a progressive tax in a declining economy. But suppose that income averaging in period 1 had saved each taxpayer a mean amount of $\$ 2$, but in period 2 , because rccession years are less likcly to produce the income growth needed to use averaging, the mean savings per taxpayer from income averaging is only $\$ 1$. This means that tax collections in the two periods would be $\$ 38$ and $\$ 33$ per taxpayer, respectively, and that aftertax incoine would decline from $\$ 162$ to $\$ 147$. In percentage terms, this decline is $9.26 \%$ - which is between the pretax decline of $10 \%$ and the $8.75 \%$ that the tax system would have produced without any averaging provisions. Thus, the dampening effect of progressive tax structures is itself dampened by averaging.

114. See MusGrave \& MUSGRAVE, supra note 58, at 306. Economists note that there are both substitution effects and income effects involved in this analysis. High rates of tax on labor income 
the latter is highly taxed and the former is untaxed. Additionally, high marginal rates also encourage investors exposed to those rates to seek tax-favored investments, which may have small, or even negative, real pretax rates of return. ${ }^{115}$ The effect of a tax systein on economic growth is thus closely linked to the efficiency of that tax system; only by minimizing the distortion of taxpayer choices among investments and between labor and leisure can a tax system achieve maximum growth. Averaging operates to initigate high inargimal rates. It does not, of course, affect all or even most taxpayers in any given year, but averaging operates unambiguously to reduce inarginal rates of those taxpayers who are affected, reducing the distortion of their labor/leisure and investunent choices.

4. Revenue. The revenue effects of income averaging are also unambiguous. In 1981, the inost recent year for which data are available, taxpayers saved just under four billion dollars by income averaging. ${ }^{116}$ It may put this figure in some perspective to note that the entire estate and gift tax revenues during the same year were estimated to be about 6.8 billion dollars. ${ }^{117}$ The revenue loss caused by the presence of the averaging provisions has grown steadily in the years since these provisions were added to the Code, as shown by Table II. The growth in real revenue loss can be best ineasured by reference to column 4, which presents the revenue loss in 1981 dollars. ${ }^{118}$

tend to induce a substitution of leisure for labor; but high rates of tax on labor also reduce disposable income, which may reduce the taxpayer's demand for leisure. Of the two, however, the substitution effect is thought to be the stronger. See Hausman, Labor Supply, in How TAXES AFFECT ECONOMIC BEHAVIOR 27, 61-63 (1981).

115. J. PeChman, supra note 58, at 74.

116. See supra note 11.

117. United States Treasury Department, Combined Statement of Receipts, ExPENDITURES, AND BALANCES 10 (1982).

118. Column 4 is produced by multiplying column 3 by the ratio of the mean consumer price index for the year to the mean 1981 consumer price index. See StatistiCal AbSTRACT, 1982-83, supra note 71 , at 452 (Table 744). 
Table II

\begin{tabular}{|c|c|c|c|}
\hline Year & $\begin{array}{l}\text { Percent of All Returns } \\
\text { Filing Schedule G }\end{array}$ & $\begin{array}{c}\text { Revenue } \\
\text { Loss (millions) }\end{array}$ & $\begin{array}{c}\text { Revenue Loss, } \\
1981 \text { dollars (millions }\end{array}$ \\
\hline$\overline{1964}$ & .38 & $\$ 133$ & $\$ 390$ \\
\hline 1965 & .45 & 171 & 430 \\
\hline 1966 & .54 & 210 & 589 \\
\hline 1967 & .74 & 253 & 689 \\
\hline 1968 & .72 & 291 & 761 \\
\hline 1969 & .78 & 294 & 729 \\
\hline 1970 & 1.35 & 536 & 1255 \\
\hline 1971 & 1.60 & 681 & 1529 \\
\hline 1972 & 1.78 & 897 & 1950 \\
\hline 1973 & 2.69 & 1418 & 2902 \\
\hline 1974 & 3.29 & 1710 & 3160 \\
\hline 1975 & 3.42 & 1413 & 2387 \\
\hline 1976 & 4.24 & 1733 & 2769 \\
\hline 1977 & 4.01 & 1895 & 2844 \\
\hline 1978 & 4.96 & 2545 & 3548 \\
\hline 1979 & 4.95 & 2977 & 3730 \\
\hline 1980 & 6.07 & 3550 & 3918 \\
\hline 1981 & 6.86 & 3781 & 3781 \\
\hline
\end{tabular}

The nearly ten-fold growth in real revenue loss since averaging was added to the Code can be explained in substantial part by rising inflation. ${ }^{119}$ Accelerating inflation has made nore taxpayers eligible to average. The averaging formula does not, of course, distinguish between real and nominal growth in taxable income; it is based sinply on a comparison of nominal mcome im the computation year with thirty percent of the nominal imcome received in the base period. ${ }^{120}$ Because the base-period data are, on average, two and a half years older than the computation-year data, it follows that inflation alone, with no real fluctuation in income whatever, can inake a taxpayer eligible for averaging if the rate of inflation is high enough to open a sufficient spread

119. Another factor contributing to the increase of revenue loss is the greater familiarity of taxpayers with averaging which has developed over time. The averaging schedule appears quite comphicated. See supra notes 87-89 and accompanying text. This was particularly true before the simplifications of the Tax Reform Act of 1969. See supra note 9. Also, it is an optional schedule, so it presents a complexity that taxpayers are not obligated to deal with if they choose not to. In any case, it is clear that, at least in the early years of the averaging provisions, a considerable number of eligible taxpayers did not exercise the option to use income averaging, even though they would surely have lowered their tax liability by doing so. See Steurele, supra note 24, at 22 (estimate that only $31.1 \%$ of all elgible taxpayers elected to use income averaging in 1971). It is possible that the greater tendency of taxpayers to use tax return preparation services, and the promotional efforts undertaken by those services, have increased public awareness of income averaging, and have increased the proportion of eligible taxpayers who elect to average.

I20. I.R.C. \& 1302(b) (1982). 
between base-period income and computation-year incoine. Further, the greater the contribution of inflation to income growth, the less real growth in mcome is required to make a taxpayer ehgible for averaging.

The introduction of income averaging roughly coincided with the beginning of a period of more or less continuously growing rates of inflation. Figure 1 shows the year-to-year consumer price index rate of change during the 1964-1981 period. Although the rate ebbs and flows, the trend is clear. More relevant for incoine-averaging purposes are the composite rates of inflation over five-year spans. Figure 2 graphs such composite rates, with the vertical coordinate for each year representing the percentage growth of that year's mean consumer price index over the mean consumer price index in the fourth preceding year. Thus, each vertical coordmate represents the inflation that took place between the first base-period year and that computation year. The fouryear composite rates smooth out the year-to-year differences and resolve any doubt that inflation has been not simply a continuing problem, but an accelerating problem over the last two decades.

The impact of inflation on eligibility for averaging can be deinonstrated in two ways: in the aggregate, by looking at the relationship between the proportion of taxpayers who elect averaging and the compound inflation rate for the preceding four years, and in particular, by examining the averaging formula itself for its sensitivity to inflationary pressures. Figure 2 presents the first demonstration. It shows that the curve representing the proportion of taxpayers electing averaging is remarkably closely linked to the composite imflation rate during the relevant five-year averaging period. In fact, the coefficient of correlation between the two variables is .966 .

This phenomenon can also be demonstrated on a disaggregated basis, for some particular income levels. With modest inanipulation, the averaging provisions yield a formula that can relate a particular rate of incoine growth to an income level sufficient to make a taxpayer eligible for averaging. If income in the first base-period year is $Y_{B I}$, then the computation-year income may be represented as $Y_{B I}\left(1+r_{I}\right)$ $\left(1+r_{2}\right)\left(1+r_{3}\right)\left(1+r_{4}\right)$, where $r_{1}$ through $r_{4}$ are the rates of income growth from each year to the next year within the five-year averaging period. This computation-year income figure must be, if the taxpayer is to be elgible for averaging, more than $\$ 3000$ greater than thirty percent of base-period income. Consistently with the representation of 


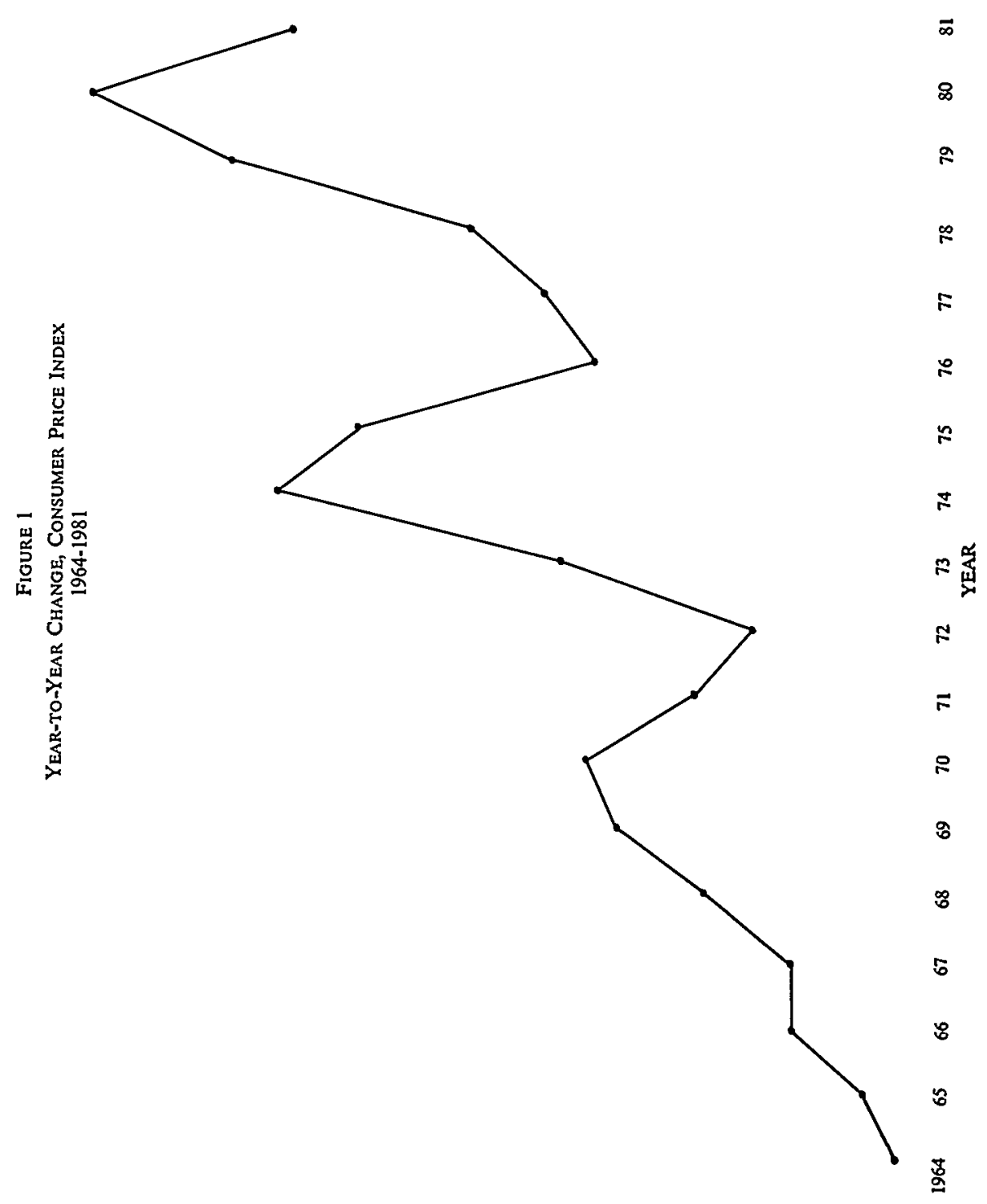

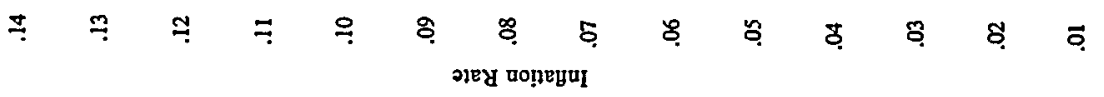




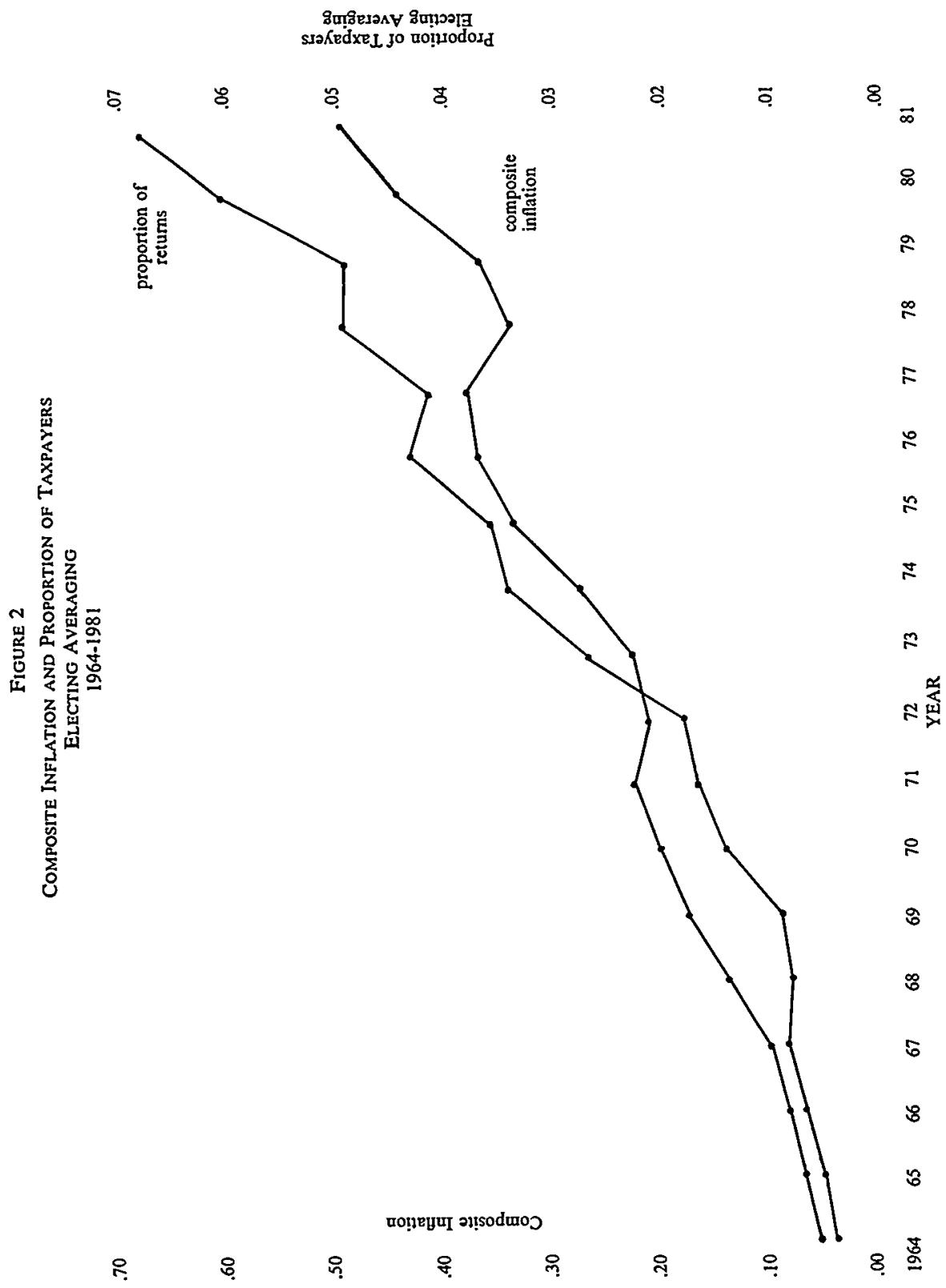


computation-year income, we can represent total base-period income as:

$Y_{B I}+Y_{B I}\left(1+r_{1}\right)+Y_{B I}\left(1+r_{1}\right)\left(1+r_{2}\right)+Y_{B I}\left(1+r_{I}\right)\left(1+r_{2}\right)\left(1+r_{3}\right)$. Rather than using hypothetical rates for the values of $r_{1}$ through $r_{A}$, it is instructive to use the actual inflation rates that have, in large part, accounted for the fact that income averaging saved taxpayers almost four billion dollars in 1981.121 Specifically, we can use the inflation rates from 1977-1981 to see at what income level inflation alone would have made a taxpayer eligible for averaging. ${ }^{122}$ Using 7.7\% for $r_{I}$ (inflation from 1977-1978), $11.3 \%$ for $r_{2}$ ('78-'79), $13.5 \%$ for $r_{3}$ ('79-'80) and $10.4 \%$ for $r_{4}$ ('80-'81), we can solve for $Y_{B !}$. Domg so, we find that a taxpayer with as little as $\$ 27,027$ of income in 1977 would be eligible for mcome averaging in 1981 if his income increased in each year within the income period by precisely the amount necessary to keep his real income constant. ${ }^{123}$ Furtliermore, if even modest real growth im income is presumed, averaging becomes routmely available at even lower imcome levels. For example, if three percent real growth is added to the 19771981 imflationary growtl noted above, a person with an income of only $\$ 13,089$ in 1977 would liave enough income growth by 1981 to be eligible for averaging in that year. And it slould be noted that real growth rates in this range are not at all unusual in certaim age groups, even in periods of little overall economic growtll. Workers in their forties typically earn more than workers in their thirties, and the latter typically earn more than workers in their twenties. ${ }^{124}$ For the average taxpayer, simply staymg im the workforce during those decades of his life is likely to be enough to create earnings growtl that, coupled with the imflation rates of recent years, will make lim eligible for averaging. ${ }^{25}$

Whether the growtl in revenue loss from averaging will continue in the future is difficult to predict, but it is possible to identify a pair of factors that may lielp staunch the outflow, and a pair that will aggravate it. First, the last two years liave witnessed the most significant abatement in the mflation rate in the last decade. This abatement can

121. See supra note 10.

122. The inflation rates relate each year's mean consumer price index with the inean index for the preceding year. STATISTICAL ABSTRACT, 1982-83, supra note 71, at 453 (Table 745).

123. It may be well to remind the reader at this point why the absolute level of the starting point-income in the first base-period year-is as important as the rate of growth in determining eligibility. The threshold amount of averagable mcome that inust be exceeded for averaging eligibility is a fixed dollar sum: $\$ 3000$. That threshold is easier to achieve if the particular growth rate is applied to a larger base. See supra notes 51-54 and accompanying text.

124. Statistical AbStract, 1982-83, supra note 71, at 438 (Table 724).

125. In 1980, for example, male full-tine workers aged 25 to 34 earned on the average $81.7 \%$ inore than such workers aged 20 to 24 . This would suggest an annual growth rate of about $8.2 \%$ between ages 22 and 291/2. Id. 
be expected to have a significant negative impact on the number of taxpayers eligible for averaging over the next few years. Whether these relatively low rates of inflation can be sustained, of course, remains to be seen.

Another factor wortl noting is that the averagmg data available from the IRS ${ }^{126}$ have not yet refiected the effect of the 1981 reduction, effective in 1982 and subsequent years, of the maximun marginal tax rate from seventy to fifty percent. ${ }^{127}$ This change is likely to make averaging less attractive to some upper-bracket taxpayers; many of them have, in 1981 and prior years, benefited fron the income-averaging effect of shifting income out of the seventy percent bracket.128 The truncating of tax brackets beginning in 1982 makes this shift autounatic - no averaging is needed. And the rate spread at the top end is now much narrower. ${ }^{129}$

On the otlier hand, the lowering of the top marginal rate was accompanied by the repeal of the maximum tax provisions, ${ }^{130}$ which differentiated between the top margmal rate that applied to "personal service income" and the top marginal rate that applied to other imcome. Simce income averaging and the maximuin tax coinputations were both elective, ${ }^{131}$ and were nutually exclusive, ${ }^{132}$ it can be predicted that some taxpayers who did not elect income averaging in 1981 and earlier years because an election under the maximum tax precluded averaging will now elect to average. Because more than half a million taxpayers

126. 1981 Statistics OF INCOME, supra note 10.

127. See Economic Tax Recovery Act of 1981, Pub. L. No. 97-34, § 101(c), 95 Stat. 172, 183 (repealing I.R.C. § 1348 (1976)).

128. See infra notes 189-201 and accompanying text for a discussion of vertical equity.

129. Under the 1984 rates, for example, taxable incomes, on a joint return, between $\$ 100,000$ and $\$ 200,000$ are exposed to a very narrow set of marginal rates: $45 \%$ from $\$ 100,000$ to $\$ 109,400$, $49 \%$ from $\$ 109,400$ to $\$ 162,400$, and $50 \%$ for incomes above $\$ 162,400$. I.R.C. $\$$ I(a)(3) (1982). Thus, thcre simply is not as much to be gained by using averaging to shift incomc from high years within this range to relatively low years. Shifting $\$ 25,000$ from a year with taxable income of $\$ 200,000$ to a year with taxable income of only $\$ 100,000$ would reduce tax by $\$ 626$ or less. In contrast, under the 1980 rates, the $\$ 100,000$ to $\$ 109,400$ income slice was taxed at $59 \%$, the $\$ 109,400$ to $\$ 162,400$ slice was taxed at $64 \%$, and the $\$ 162,400$ to $\$ 215,400$ slice was taxed at $68 \%$, 1.R.C. $\$ 1$ 1(a) (Supp. IV 1980). Shifting $\$ 25,000$ from a $\$ 200,000$ year to a $\$ 100,000$ year under this rate structure could save up to $\$ 1470$. Note that this is the "fluctuation penalty." How nuch of this penalty is relieved by averaging depends on circumstances not detailed in this hypothetical example.

130. I.R.C. $\$ 1348$ (1976), repealed by Economic Recovery Tax Act of 1981, Pub. L. No. 97-34, $\S 101(c), 95$ Stat. $172,183$.

131. See supra note 57 and accompanying tcxt.

132. I.R.C. § 1304(b) (1976) amended by Economic Recovery Tax Act of 1981, Pub. L. No. 9734, 95 Stat. $172,183$. 
used the maximum tax in $1981,{ }^{133}$ and because they tended to be taxpayers who are in income brackets that make heavy use of averagmg, ${ }^{134}$ this group inay be a significant source of new averagers in the years after 1981 .

Demographic factors will also operate to encourage averaging for at least the next decade. Age-specific earnings data suggest that fulltime workers experience considerable income growth while in their twenties and thirties, with only modest gains, if any, thereafter. ${ }^{135}$ Since the baby boom peaked in 1957 and did not significantly subside until 1965,136 the proportion of workers in the workforce who are in high-growth phases of their careers is likely to contmue to increase until the middle-to-late 1990's.

Without a computer model, and perhaps even with one, the resultant vector of these countervailing trends cannot be determined with any confidence. I offer the following intuitive guesses: (1) the abatement of inflation is unreliable, since much or most of that abatement has been the product of the 1980-1982 recession; inflation projections are now swinging back up, ${ }^{137}$ and inflation seems bkely again to provide significant impetus for averaging; (2) the demographic trend is a significant one-there will be about $10.9 \%$ more workers aged twenty to thirty-nine in 1990 than there were in $1980 ; 138$ (3) the truncating of

133. An estimated total of 544,920 taxpayers filed maximum tax computations in 1981. 1981 STATISTICS OF INCOME, supra note 10 , at 72 (Table 3.1, col. 1).

134. Of the 544,920 taxpayers who used the maximum tax provisions in 1981, 453,325 had adjusted gross incomes between $\$ 50,000$ and $\$ 200,000$. Id. Over one-third of the taxpayers in those income brackets used imcome averaging in 1981. Id. See also supra note 103.

135. See supra note 124.

136. Historical Statistics of the United States, Colonial Times to 1970,49 (1975) (Series B: Live Births, Deaths, Marriages, and Divorces: 1909 to 1970). Approximately 4,308,000 live births were recorded in 1957. The number of live births each year through 1964 continued to be in excess of four million. In 1965, the number of live births declined to about $3,760,000$, from which level the rate generally contimued to decline modestly for the balance of the decade. Id.

137. Predicting infiation rates is not something that can be done with any real confidence. As this article goes to press, however, many economic analysts believe that the rate of inflation by the end of 1984 is likely to be in the 7-to-8\% range. See, e.g., Wall St. J., Apr. 4, 1984, at 1, col. 6. At least one Nobel-laureate economist has predicted that the rate will reach $9 \%$ by year end. See Guzzard, The Dire Warnings of Milton Friedman, FoRTUNE, Mar. 19, 1984 at 28. This represents a sizable increase over the 1983 inflation rate of 3.8\%. Wall St. J., Jan. 25, 1984, at 2, col. 2.

138. U.S. Census, 1980, General Population Characteristics 1-26 (1983) (Table 42). The Census reveals that, as of the Spring of 1980, the ten-year cohort of persons in their teens numbered about 39 million; the cohort in their twenties numbered about 41 million; the cohort in their thirties numbered about 32 million. By 1990, the first cohort will have replaced the last cohort in the income-growth years of $20-39$, resulting in the $10.9 \%$ increase noted in the lext. Mortality in these age groups is very low; in fact, it appears to be more than offset by immigration. Id.

One perplexing finding of the Steurele study, supra note 24 , should be noted in this context. They found that the median age of income averagers was 46 in the tax years between 1967-1971. 
brackets will reduce revenue loss at the top end of the income distribution, and somewhat lessen the vertical equity problein posed by averaging; but, (4) the truncatimg of brackets will be largely offset by the impetus to average provided by the repeal of the maximuin tax provisions. The conclusion inust be that the revenue loss from incoine averaging is likely to increase modestly, absent any legislative change, over the next several years.

5. Summary. An analysis of the "pragmatic" tax policy criteria is of some significance. If the more crucial "equitable" criterion is closely balanced, and the "pragmatic" criteria are overwhelmingly positive or negative, the overall judgment of the tax feature must be made largely on the basis of the "pragmatic" criteria.

As to income averaging, however, the foregoing analysis of the "pragmatic" factors has served primarily to focus attention on the importance of the "equitable" factors because of the balance within and among the "praginatic" factors. Averaging appears to nudge the tax system modestly in the direction of efficiency. Though it has some genuinely difficult problems of complexity, and presents a demoralizing appearance of coinplexity to taxpayers, it is nevertheless fairly free of legal ambiguity, and subject to fairly inechanical and inexpensive administration. It has moderate tendencies to dilute the stabilizing infiuence of the graduated rate structure. Finally, at a revenue cost of four billion dollars per year-an amount which, absent congressional changes to the system, seems unlikely to shrink in the near future-it is expensive, but not prohibitively so. If that four billion dollars buys substantial improvement in the equity of the system, it may not be too high a price to pay. If, conversely, it results in relatively little improvement in equity, a four billion dollar revenue loss looms large. The next section examines the equity issue in detail.

Id. at 21. This seems odd in light of the fact that income growth is more pronounced in younger age-groups. To some degree, the high median age reflects the fact that during those years, older taxpayers who were eligible had a much greater propensity to elect averaging. Id. at 22 . With the overall increase in the use of averaging, this age-group differential is probably much smaller today. Of course, Steurele's data also reflect the impact of the self-support requirement on the eligibility of many younger taxpayers, see supra notes 55-57 and accompanying text, and perhaps also the age-differential effect of the $\$ 3000$ ininimum averagable income. See supra notes 51-54 and accompanying text. These latter influences will presumably continue to disqualify from aver* aging many younger taxpayers who have experienced fluctuation penalties.

However, even if it contmues to be true, as it was im Steurele's study, that use of averaging, by age group, peaks in the forties age-bracket, there is still a demographic basis to predict that use of averaging will imcrease. In 1980, there were fewer than 23 million individuals in their forties in the U.S., reflectimg low depression-era birth rates. U.S. Census, 1980, General Population Characteristics 1-26 (1983) (Table 42). By 1990, the number of persons in their forties will have risen to nearly 32 million, a $38.5 \%$ increase. $I d$. 


\section{B. The Equitable Criterion.}

The fairness of a tax system involves two quite distinct elements. First, the system should avoid inaking arbitrary distinctions among more or less equally situated individuals; the system should not burden some individuals significantly more than others on the basis of trivial differences in economic status. ${ }^{139}$ Second, the system should distribute the overall burden fairly, but not necessarily evenly, among groups of taxpayers whose receipt of governmental benefits, and abihity to bear tax burdens, may differ widely. ${ }^{140}$ The two concepts are generally referred to as horizontal equity and vertical equity, respectively.

The primary motivation for adding the income averaging provisions to the federal tax code was to improve the horizontal equity of the system. ${ }^{141}$ It was thought to be unfair to burden equal multiyear incoines differently inerely because soine were received in relatively even annual amounts while others were received erratically. ${ }^{142}$ The following subsection evaluates income averaging in terms of several different aspects of the horizontal equity problem.

1. Horizontal Equity-The Timing Dilemma. It was noted earlier that fluctuating incoines pose a horizontal equity problem in a tax system that has both a progressive rate structure and an annual accounting requirement. ${ }^{143}$ This statement of the problem reflects the conventional view that taxpayers with fiuctuating incomes are "penalized" by having their high-incoune years exposed to high tax rates, and invites proposals to dimimish or eliminate the "fluctuation penalty." 144 In fact, this conventional view subtly prejudices the policy prescription by ignoring the double-edged nature of the inequity created by fluctuating incomes. Fluctuating incomes do pose a problem, but it is a problem in the forin of a dilemma.

The nature of the dilemma can be seen by examining the initial example in this article, ${ }^{145}$ which compares the tax treatment of two taxpayers with lifetime incomes of 50x. One receives that income in equal

139. See Musgrave \& MuSgrave, supra note 58 , at 235.

140. See id. at 238.

141. The legislative history of income averaging is bare of any statements that would support the notion that income averaging was intended to shift burdens anong income groups.

142. "Incoine averaging, in your committee's view, should be designed to treat everyone as nearly equally for tax purposes as possible, without regard to how their income is spread over a period of years and without regard to the income involved." H.R. REP. No. 749, 88th Cong., 1st Sess. 110, reprinted in 1964 U.S. CODE CONG. \& AD. NEws 1313, 1419.

143. See supra note 1 and accompanying text.

144. See J. Pechman, supra note 58, at 121.

145. See supra note 2 and accompanying text. 
annual amounts of $x$, while the other receives an income of $2 x$ in soine years, and an income of zero in other years. The individual with the fluctuating income will, over the course of her lifetime, pay more tax than the person with the steady income, unless some provision is added to the tax structure to relieve the fluctuation penalty. If such a provision is added to a tax code, however, a new horizontal inequity is created. Under virtually all workable averaging devices-including the one presently in use in the United States-the fluctuation rehef takes the form of reducing the tax hability of this fluctuating taxpayer, in the years in which her income is $2 x$, to an annount significantly below the tax paid by other taxpayers who have incomes of $2 x$ in that year. Thus, movement toward horizontal equity between two taxpayers of equal lifetime incomes inakes the system less horizontally equitable for pairs of taxpayers with the same annual incomes.

Definitions of horizontal equity are typically vague concerning the period over which it is to be gauged. The principle is simply that "similarly situated people should be treated similarly, that equals should be treated equally." 146 At least one cominentator, Judge Sneed, has attempted to add rigor to the definition by including a time dimension: "The [horizontal equity] criterion asserts that those whose consumption and net accretion of wealth during a given period are equal [should be treated equally]." 147 Judge Sneed's purpose in this statement was to engraft the conceptual soundness and widespread acceptance of the Haig-Simons accretion definition of income ${ }^{148}$ onto an otherwise spongy horizontal equity criterion. He no doubt did not intend to express a view on the desirability or necessity of income averaging. Nevertheless, there is virtually universal recognition of the general suitability of the annual accounting period for income measurements, ${ }^{149}$ and under Sneed's definition, the horizontal equity criterion would therefore be best satisfied by a system that does not permit averaging.

Those tax commentators who have focused explicitly on incomefluctuation problems have held, as a group, the opposite view. Expressly or implicitly, they believe that horizontal equity inust be evaluated in terms of lifetime or multiyear incomes, not annual income. ${ }^{\text {s5o }}$ Despite the popularity of the lifetime or multiyear view, lowever, there

146. W. Klein, Policy Analysis of the Federal Income Tax 7 (1976).

147. Sneed, supra note 58 , at 579 (emphasis added).

148. See H. Simons, Personal Income Taxation 50 (1938).

149. See, e.g., Burnet v. Sanford \& Brooks Co., 282 U.S. 359 (1931).

150. See, e.g., Ferguson \& Hood, Income Averaging, 24 TAX L. REv. 53, 53 (1968); Smith, How' to Become Miss America Without Achieving Any 'Major Accomplishment'-Some Thoughts on Income Averaging Provisions of the Internal Revenue Code, 54 MARQ. L. REv. 329, 330 (1971). 
are powerful arguments for the annual view. This is particularly the case in situations where the taxpayer does not anticipate the change in income. To illustrate, imagine a taxpayer $\mathrm{A}$ who is a likely candidate for averaging under the present system. In 1983, as in at least a few prior years, $\mathrm{A}$ is a minor league baseball player, earning an income of $x$. In 1984, A finally makes it to the major leagues, and is passably successful. His salary increases to $3 x$. A will surely bear a substantial fluctuation penalty. The conventional tax policy view is that this should be reheved somehow, that A should pay no more tax than a taxpayer whose income in both 1983 and 1984 was $2 x$. To accept this approach, however, is to impose quite an artificial view on A's perceptions, behavior and lifestyle; it is very likely that im neither year did A hive in the manner of a taxpayer with an income of $2 x$. In 1983, he lived like a taxpayer with an mcome of $x . X$ was the appropriate measure of his ability to pay in that year. In 1984 , he had an income of $3 x$, presumably lived in a manner similar to others who enjoy that income, and probably had an ability to pay tax that is appropriately ineasured by that income. While it is true that $\mathrm{A}$ had a two-year income that is equal to that of a taxpayer with an income of $2 x$ in each year, the latter is nevertheless a false paradigm for purposes of determining A's ability to bear tax burdens. A should be taxed for what he is: a taxpayer with an mcome of $x$ in 1983 and a taxpayer with an income of $3 x$ in 1984.

A brief examination of the reasons for a progressive income tax structure clarifies the underlying perceptions which inform and support this argument. This is, of course, a subject about which volumes liave been written. ${ }^{151}$ Rather than reflecting the entire range of the considerable scholarship in this area, it should suffice to present a short and minimally controversial suminary of the inost salient features of the case for a progressive tax.

The startimg point of such a summary must be the msight that income has declining margmal utility. Every household has its consumption priorities. If resources available for consumption are ineager, those resources will be marshaled to buy the most important items. As resources increase and consumption opportunities develop, items are added to the household budget that are less essential. The absolute amount of utility that results from expanded consumption opportunities may be high, but it surely must be lower than the utility derived from the first dollars of income. This perception is no more than a direct inference from the principle that households maximize utility. If

151. See, e.g., W. Blum \& H. Kalven, The Uneasy Case for Progressive Taxation (1953); Blum, Revisiting the Uneasy Case for Progressive Taxation, 60 TAxEs 16 (1982); Slemrod, Do We Know How Progressive the Income Tax System Should Be?, 36 NaT'L TAx J. 361 (1983). 
consumption of the $n$th dollar of mcome gives the household more satisfaction than the average of all dollars less than $n$, the household will not have maximized utility at incoine levels below $n$; it could have substituted the purchase inade with the $n$th dollar for some purchase that yielded less utility. Because the concept that marginal utility of income for a particular household generally declines is mathematically demonstrable, it is umversally accepted by economists, so long as they accept the more basic presumption that consuiners maximize utility. ${ }^{152}$

The essence of the case for a progressive tax is that burdens should be distributed evenly. But burdens should be measured by utility sacrificed to the government, not by the dollar levels of taxes. Linking declining marginal utility of income to progressive incoine taxes requires two further steps. These are not uncontroversial, and it may be best simply to state a personal view of the best case for a progressive tax. One must first choose a standard by which the evenness of sacrifice is to be measured. ${ }^{153}$ The choice preferred by this author is the equal proportional sacrifice theory ${ }^{154}$ - that each taxpaying uint should pay enough dollars in tax that the utility lost to the tax, as a percentage of total pretax utility, is roughly constant among all taxpaying units.

The second step in linking declining marginal utility to progressive taxes is to develop a means of comparing households' utility curves. To say that each lousehold's marginal utility curve declines is not to say that all decline at the same rate or from the same level. Indeed, it seems

152. There are a few economists who would quibble with this more basic assumption, largely on the grounds that consumers' tastes are not exogenous. To the extent that tastes are manufactured for consumers by advertisers, the whole concept of utility assumes a somewhat artificial quahty. The best-known proponent of these views, of course, is John Kenneth Galbraith, who has amplified this basic thought in both The Affluent Society (1958) and The New Industrial State (1967).

153. The three standard choices are equal absolute sacrifice, equal margimal sacrifice, and equal proportional sacrifice. MUSGRAVE \& MUSGRAVE, supra note 58, at 250-53. Under the "equal absolute sacrifice" concept, each taxpayer is taxed to the extent that his utility lost to taxes is the same as every other taxpayer's utility loss resulting from the tax. Under "equal marginal sacrifice," taxpayers in the aggregate pay as taxes those dollars that yield the least utility, so that the aggregate utility loss is minimized. Under "equal proportional sacrifice," each taxpayer pays an equivalent fraction of imcome, using as the numerator the utility lost to the individual taxpayer through the payment of tax, and using as the denominator the total utility afforded the taxpayer by his pretax income. Id.

154. One economist who has studied the United States income-tax bracket structure has concluded that the equal absolute sacrifice theory provides the inost consistent explanation of the rate structure over time. Mera, Experimental Determination of Relative Marginal Utilities, 83 J. of ECON. 464, 472-73 (1969). My reading of his data, however, suggests that the difference between equal absolute sacrifice and equal marginal sacrifice, im terms of how well each explains congressional tax-rate decisions, is very unodest. The data Mera studies, rate schedules from 1948 to 1965 , seem reasonably consistent with either theory. Id. Compare id. at 472 (Figure II) with id. at 473 (Figure III). 
probable that neither of these is true. How then can a tax rate structure be imposed that will equilibrate proportional sacrifice?

One promising ineans of lending objectivity to the utility analysis is to evaluate sacrifice in terms of "social utility."15s The social utility concept ignores the subjective utility actually received by the household. There is a clear loss of information in this, and perhaps some loss of justice. Some individuals no doubt work very hard, make large investinents in liuman capital, and seek out the most remunerative employments of their skills precisely because their margmal utility curves are nearly flat; they continue to get a great deal of utility from additional increments of incoine even at levels at which other individuals would be sated. On the other hand, it may not be inappropriate for society to conclude that a taxpayer's high personal utility from uses of certain resources-such as a second Rolls Royce-lias less social worth than alternative uses. ${ }^{156}$ The social utility concept, then, gives every household the same utility curve-not on the grounds that they actually have the same utility curves, but on the grounds that they may be appropriately treatcd as though they did. A tax structure that will equilibrate proportional sacrifice of social utility may then be deduced from this social utility function. ${ }^{157}$

To illustrate this approach in an income-averaging context, imagine the following very simple social utility function:

155. See Musgrave \& Musgrave, supra note 58, at 253-54. See also Stern, The Marginal Valuation of Income, in Studies of ECoNOMIC ANALYSIS 209 (1977) (for a list of useful references, see $i d$. at 250-53).

156. The idea of imposing, in effect, the same utility schedule on everyone would be less troubling if a comprelensive tax base could be employed in the tax system. It would be thoroughly impractical to do so, of course, and even the theoretical concept of a coinprehensive tax base may be somewhat ephemeral. See generally Bittker, supra note 61. Nevertheless, in the absence of a comprehensive tax base, gross inequities can arise by using a social utility approach. If we imagime two individuals of equal and large earning capacities, one of whom has strong tastes for money and the things it can buy, the other of whom has a strong taste for leisure, we can see that the first individual will sacrifice much more of his utility im a progressive tax system based on social utihty than will his leisure-loving counterpart.

157. The tax structure so inferred is not a progressive one as a matter of matheinatical necessity; one can imagine social utility functions under which the equal proportional sacrifice doctrine does not require progressivity. Mera's implicit social utility function, see supra note 154, does require, however, a progressive tax, as does the hypothetical structure I describe in the text. The case for a progressive tax as outlined in the text must therefore stipulate a particular social utility function, or perhaps a group of such functions having important common characteristics in order to validate the progressivity element of the tax structure. There is some circularity in this; one is left with justifying a progressive tax by saying that one is willing to stipulate a social utility function under which only a progressive tax will exact equal proportional sacrifice. Mera's article, in fact, involves preeisely this sort of bootstrapping. See Mera, supra note 154. Despite this difficulty, however, I am willing to go along with the view that the appropriate social utility schedule is one which dennands a tax system with at least some progressivity. 


$\begin{array}{lc}\$ 0-10,000 & \frac{\text { Utility/Dollars }}{3 \mathrm{utils} / \text { dollar }} \\ \$ 10,000 \text { and over } & 2 \mathrm{utils} / \text { dollar }^{158}\end{array}$

And imagine a tax rate schedule roughly reflecting an equal-proportional-sacrifice doctrine:
$\underline{\text { Income }}$
$\underline{\operatorname{Tax}}$
$\$ 0-10,000$
$20 \%$ of income
$\$ 10,000$ and over
$\$ 2000$ plus $40 \%$ of excess over $\$ 10,000$

Finally, imagine two taxpayers: $A$, who earns $\$ 5000$ in year one and $\$ 15,000$ in year two, and $\mathrm{B}$, who earns $\$ 10,000$ in each year. Combining in Table III these income numbers with the social utility and tax functions specified above, we can compute pretax income, taxes, and after-tax income for $\mathrm{A}$ and $\mathrm{B}$, in terms of both dollars and utility.

\section{Table III}

$$
\text { A }
$$

\begin{tabular}{|c|c|c|c|c|c|c|}
\hline \multirow[b]{2}{*}{ Yeal } & \multicolumn{3}{|c|}{ Dollars } & \multicolumn{3}{|c|}{$\underline{\text { Utils }}$} \\
\hline & Income & $\operatorname{Tax}$ & Aftertax & Income & Tax & Aftertax \\
\hline 1 & $\$ 5000$ & $\$ 1000$ & $\$ 4000$ & 15,000 & 3000 & 12,000 \\
\hline 2 & $\underline{15,000}$ & 4000 & $\underline{11,000}$ & 40,000 & 8000 & 32,000 \\
\hline total & 20,000 & 5000 & 15,000 & 55,000 & 11,000 & 44,000 \\
\hline
\end{tabular}

$B$

\begin{tabular}{|c|c|c|c|c|c|c|}
\hline \multirow[b]{2}{*}{ Year } & \multicolumn{3}{|c|}{ Dollars } & \multicolumn{3}{|c|}{ Utils } \\
\hline & Income & Tax & Aftertax & Income & Tax & Aftertax \\
\hline$\underline{E}$ & $\begin{array}{r}\$ 10,000 \\
10,000 \\
\end{array}$ & $\begin{array}{r}\$ 2000 \\
2000 \\
\end{array}$ & $\begin{array}{r}\$ 8000 \\
8000 \\
\end{array}$ & $\begin{array}{l}30,000 \\
30,000 \\
\end{array}$ & $\begin{array}{l}6000 \\
6000 \\
\end{array}$ & $\begin{array}{l}24,000 \\
24,000 \\
\end{array}$ \\
\hline total & 20,000 & 4000 & 16,000 & 60,000 & 12,000 & 48,000 \\
\hline
\end{tabular}

Obviously, the left side of Table III inakes the conventional case for income averaging. $\mathrm{A}$ and $\mathrm{B}$ have the same two-year incomes, but $\mathrm{A}$

158. This particular schedule of utility and tax rates is not a general one; that is, it will not produce equal proportional sacrifice for all taxpayers. The income numbers in the example were chosen precisely because they did produce equal proportional sacrifice. Using more complicated mathematics, it would be possible to determine a more general equal proportional sacrifice tax rate schedule, although a perfect one would require marginal tax rates to vary continuously, not by brackets. For this example, that complication would surely be counterproductive. The point of the example is simply that fluctuation penalties measured in dollars may not turn out to be penalties at all if measured in utility terms, as they ought to be in evaluating taxpayer sacrifice. 
pays twenty-five percent more tax-a fluctuation penalty of $\$ 1000$. On the right side of Table III, however, this fluctuation penalty evaporates. Because A's tax penalty was incurred in a year in which his marginal incoine produced less marginal utility, his sacrifice was no greater than B's. Both A and B have sacrificed twenty percent of their pretax utility to the government by the payment of taxes, and have thus satisfied the equal proportional sacrifice standard.

There is within this analysis a critical but perhaps not wholly obvious assumption: The analysis works only if it is appropriate to bifurcate the two-year experience into two annual parts, each plotted separately on the taxpayers' annual utihty of income curves. If one were to construct a biennial utility curve, A and B would have the saine total utility, and A's greater dollar tax bill would be associated with a greater absolute and proportional utility sacrifice. This example thus illustrates the importance of the choice of time period over which horizontal equity operates, but it does hittle to resolve that choice.

Proof of the superiority of the annual view is difficult to adduce. It must also be adınitted that $\mathrm{m}$ this as in all areas, the annual accountimg period is unlikely to work perfectly. Utility curves represent a taxpayer's perceptions of his consumption opportunities at any given time, and his judgments about his position on such a curve will change in response to discrete events-a salary increase, a stock market slump, etc.- that do not necessarily coincide with either a calendar year or any other tax year. Nevertheless, the annual period seems roughly accurate for sacrifice evaluation purposes, just as it seems roughly accurate for purposes of computing income. As noted above, the ability of the taxpayer to anticipate his future income levels with some precision and confidence is the key. If one knew at the beginning of a two-year (or a five-year) period what one's income would be during that period, then that period would surely be the appropriate period over which to measure utility and sacrifice. In the absence of such knowledge, however, the usual annual accounting period has substantial appeal.

This is best seen by exainining some obvious counterexamplestaxpayers for whom an annual sacrifice assessment seems inappropriate-and by noting how rare or unlikely such counterexamples are. The archetype of taxpayers for whom a five-year view would seem appropriate would be a novehist or inventor who spends four years developing a book or invention, and sells it in the fifth year. Or, in a somewhat less creative vein, one might imagme a lawyer who spends five years preparing and trying a large contingent fee case or an entrepreneur who spends five years developing a new product. Certainly, such taxpayers exist, perhaps in significant numbers. For the five-year 
sacrifice evaluation to be fully appropriate, however, one must assume a few additional - and not very likely-facts: that the taxpayer was reasonably certain of achieving a favorable outcome at the end of his five-year sojourn; and that he lived accordingly during the five-year development period, financing a fairly regular consumption pattern out of prior income or borrowing.

Far more likely is the following scenario: During the years in which our novelist, for example, is preparing her first book, she lives like a graduate student in a small and sparsely furnished apartinent in an artsy but essentially deplorable neigliborlooo. She devotes substantial parts of her work week to waiting on tables or driving a taxiindicating by lier market behavior that incoine lias a higl utility for her, else she would not work so hard for so little of it. She hopes that her novel will be a huge success and will radically alter her consumption opportunities, but she has no firm basis for confidence that those hopes will be fulfilled. Assume that when her novel is finished and published it is precisely the huge success she lioped for. Our novelist then moves to a nicer apartment in a nicer neigliborhood, thougli she spends much of her time at lier 200 year-old Connecticut farmhouse with her Russian wolfhound. When the royalties froin the initial wave of sales begin to taper off slie goes on lecture tours at $\$ 5000$ per stop and negotiates with her publisher to receive a sizable advance on her second book, perhaps designed with increasing periodic payinents to offset the decline in royalty income front the first book. If slie is welladvised-and a sizable industry exists for no other purpose tlian to provide such advice-slie will structure her professional life to accomplish a good deal of mcome shifting or deferral by means of Keogh plans, royalty assignments to trusts, Individual Retirement Accounts, and the like. ${ }^{159}$ This will not only reduce ler current tax burden, but will provide a soft landing sliould slie ever run out of creative fuel.

This scenario deserves some reflection. Novelists with this approximate career pattern provide a major arclietype for advocates of income averagmg. They are cited in committee reports, ${ }^{160}$ congressional testi-

159. A nice detailing of the state of the art, circa 1980, of deferring income for upper-bracket creative people can be found in George Cooper's delightful article, Cooper, The Avoidance Dynamic: A Tale of Tax Planning, Tax Ethics, and Tax Reform, 80 Colum. L. Rev. 1553 (1980). Cooper's point is that the state of the art may be far too artful, but I presume that my novelist would be no more concerned with the ethical aspects of tax planning than was Cooper's Sally Songwriter.

160. See, e.g., H.R. ReP. No. 749, 88th Cong., 1st Sess. A174, reprinted in 1964 U.S. CodE CONG. \& AD. NEws 1313, 1599. 
1nony, ${ }^{161}$ and articles. ${ }^{162}$ Yet it is hard to discern any real injustice in the way the tax system treats such individuals. During her years of relative poverty, our novelist will be taxed very lightly, if she pays any federal income tax at all. 163 When she achieves great success, her lifestyle is changed, and so is her margmal tax rate. It is not clear why the fisc owes her any special tax rehef at that time because of her prior poverty; nor is it clear that she should bear any lesser tax burden after she becomes wealthy than her Connecticut neiglibors who have the same incomes in those years.

Moreover, once our lyppothetical novelist ascends to upper-bracket income levels, she is in a position to do a significant anount of selfaveraging. She can take advantage of the several congressionallyblessed imcome-deferral opportunities. ${ }^{164}$ She can decide when to lecture, when to seek an advance for her next book, and how that advance and subsequent royalties are to be structured. Similar postsuccess opportunities for control of the income flow exist in other fields that are promment in the mcome-averaging literature. An inventor controls his patent hicensing arrangements and has a better chance to secure a steady flow of research and development contracts after he has proven himself. A successful lawyer has a wider choice of clients and fee arrangements. An entrepreneur may incorporate her busmess; control of both her dividend flow and the exercise of her stock options would give her a substantial ability to regularize mcome flow.

Of course, the present averaging system is not based on lifetime income, and thus does not permanently favor the hypothetical novelist over her Connecticut neighbors simply because the former was poor for some portion of her life. A few years after her ascent to a high level of success, presuming slie does not continue on to new and higher levels, she will find that her base period begins to imclude her first successful years and that averaging produces less savings. After three or four years, the averaging mechanism will have forgotten, as it were, her former poverty, and she will no longer be eligible for averaging. Is there then a defense of the present averaging mechanism to be made in terms of a purely temporary favoritism? Is there, in other words, reason to believe that our novelist, at least for a few years after her flrst success, is

161. See, eg., Tax Reform: Hearings before the House Comm. on Ways and Means, 91st Cong., 1st Sess. 1935 (1969) (statement of Michael Waris, Jr.).

162. See, e.g., Ferguson \& Hood, supra note 21, at 91; Smith, supra note 150, at 344.

163. A single person with a gross income of $\$ 8000$ who takes a personal exemption of $\$ 1000$, for example, would pay a inaximum of $\$ 610$ of federal mcome tax, under 1984 rates. See I.R.C. $\$ 1(c)(3)$ (1982).

164. See Cooper, supra note 159, at 1554-72. 
less able to bear sizeable tax burdens than those who have been in her income bracket for a number of years?

There is some appeal to this argument. One who has only begun to earn a high income is surely not as well off as one who has earned an equivalent income for many years. The difference, of course, is one of wealth. If our newly successful novehst is compared with an older counterpart, a novelist who has been successful for twenty years, one would expect the latter, through savings and investments, to have attamed more wealth than the newly successful novehst. Comparing these two individuals head-to-head, however, involves a considerable amount of fudging on the horizontal equity criterion. First of all, comparisons based on wealth are somewhat mappropriate when one is evaluating an income tax. The United States does not tax wealth directly, ${ }^{165}$ and has thus determined to address horizontal equity not in terms of wealth, but only in terms of income. And even in terms of income, the comparison of the older novelist with the equally successful younger one is to some degree inapt. Because of their differences in wealth, it could be inferred that, all else being equal, the older novelist is likely to have more income from investunents and less interest expense on consumer and mortgage loans than the younger novelist. ${ }^{166}$ Thus, though the two novelists may appear coinparable in terms of earnings from writing and lecturing, it is likely that the younger novelist will not be taxed as lieavily as the older one, even without income averaging, simply because she has less income and inore deductions. Comparison of these two individuals, then, does not advance a valid horizontal equity argument in favor of averaging, because the two are, in a fundamental way, not equally situated. Further, the inequality of their situations would be reflected in their taxes without resort to averaging.

165. There is, of course, a tax on the transfer of wealth. See 1.R.C. $\$ \S 2001,2501$ (1982) (estate and gift taxes). Stationary wealth, however, is immune.

166. In the real world this may not be completely accurate. Our older novelist may well have spent much of the twenty years since his first great success mastering the ways im which tax burdens can be avoided. His substantial wealth may be invested in municipal bonds, an even larger and older Connecticut farmhouse, oil drilling, equipment leasing, and other investments designed precisely not to produce any additional taxable mcome, and perhaps even to shelter some of his writing income. True as this may be, it nevertheless cannot seriously be maintamed that income averaging is defensible as an antidote to the problem of erosion of the tax base at the upper end of the income distribution. This would amount to an argument that averaging is necesary to give our younger novelist a few years to learn how to play the shelter game. The fact is that if the older novelist has more wealth, he should have more economic imcome, and if the tax systein fails to translate that economic mcome into taxable mcome, it is because of failings that have nothing to do with income averaging. 
The prototypical averaging cases therefore suggest: (1) that averaging is not generally necessary when the taxpayer is ascending to the upper income brackets, because the annual assessinent of utility sacrifice provides the more accurate representation of the taxpayer's situation; and, (2) that once that ascent is complete, the taxpayer will typically have enough control over future income that he can minimize fluctuation penalties.

One objection that could be made to these generalizations is that they are, even if accepted as substantially true, no more than generalizations. One might argue that averaging is needed nevertheless to take care of those situations im which the taxpayer's hifestyle does not fully adjust to the current income level, perhaps because of the obvious impermanence of that income level, and the taxpayer has no real control over future income flows. The best example may be a taxpayer of modest baseline income who wins a large lump-sum lottery. ${ }^{167}$ The taxpayer knows that the income bulge will not likely be repeated, and he will-for purposes of assessing his consumption opportunities-implicitly annuitize the lottery award over his remainimg life. ${ }^{168}$ Under this approach, the taxpayer's consumption opportunities do widen, but the extent of the improvement would be vastly overstated by that year's income. Absent some form of averaging, however, that year's mcome would be the basis of the utility sacrifice computation performed by the tax system.

It must be conceded that the presence of averaging for such cases inproves the fairness of the tax system. If such cases can be culled from other situations im which income fluctuates but no real inequity exists, then the tax system should attempt to do so. Some of the proposals made below offer hope of distinguishing the cases deserving rehef from those that do not. ${ }^{169}$ If, on the other hand, it is determined that the tax system cannot distmguish fluctuation situations deserving relief from those not deserving relief with sufficient accuracy in a sufficiently admimistrable nnanner, then it must be recognized that one of

167. It is my impression that most of the legal lotteries in the United States, however, pay their largest awards in twenty-year or lifetime allotments, which eliminates the fluctuation problem in that the postlottery annual income of the winner accurately measures his annual consumption opportunities, and the normal tax schedule will exact the appropriate utility sacriflce.

168. This hypothetical example comes very close to the actual facts of Goldstein v. Commissioner, 364 F.2d 734 (2d Cir. 1966), a gambling-winnings case, which arose prior to the advent of income averaging, discussed infra at note 247 and accompanying text. Ironically, gambling winnings, which present perhaps the best case for multiyear averaging, were imtentionally excluded from the averaging provisions fron 1964 until 1969.

169. In particular, my Tax Averaging Account proposal, infra notes 247-58 and accompanying text, would offer, I believe, nearly perfect relief for the one-year lottery winner. 
the costs of achieving the appropriate multiyear horizontal equity in the lottery case will be the creation of substantial and inappropriate horizontal inequities on an annual basis for the athletes and novelists whose situations were discussed earlier. ${ }^{170}$ If this essential trade-off is observed, then the appropriate solution inust be to design the system to deal with the relatively common case, not the relatively unusual one. For the reasons explained earlier, mcome averaging in the inore coinmon case can be inore accurately viewed as causing annual liorizontal inequity, rather than as relieving multiyear horizontal inequity.

2. Horizontal Inequity in the Present System. The preceding subsection was intended to show that the horizontal equity case for any income-averaging system is much weaker than is generally supposed. The intention of this subsection is to remind the reader, regardless of his convictions concerning the theoretical need for income averaging, that the existing federal averaging system provides only sporadic relief for fluctuation penalties.

The present averaging provisions appear to be quite general. They apply to all types of incoine, ${ }^{171}$ and to taxpayers in all income brackets, marital situations, and age groups. These provisions were designed to provide an averaging device that would be "generally available," 172 and were intended to replace the hodgepodge of special provisions that existed prior to $1964 .{ }^{173}$ These efforts at achieving generality must be judged a failure, however, for the apparent generality breaks down at so many points as to be largely spurious.

Most of the departures from generality were quite intentional, if ill-advised. Congress consciously chose to make it difficult, although not uniformly so, to achieve eligibility for averaging early in one's career. ${ }^{174}$ Congress also chose not to allow averaging in years when income declines. ${ }^{175}$ These choices preclude averaging for many taxpayers who would seem to be as deserving as anyone of relief from fluctuation penalties. For example, imagme the plight of a football player who goes directly from college to a lucrative but brief professional career, after which lie coaches higli-school football. He may have earned literally eighty percent of his real lifetime earnings be-

170. See supra notes $150,159-66$ and accompanying text.

171. That is, they apply to earnings from employinent or self-employinent, earnings from capital, and, since 1969, capital gains and gambling earnings.

172. H.R. ReP. No. 749, 88th Cong., Ist Sess. 25, reprinted in 1964 U.S. CoDE CoNG. \& AD. NEWS $1313,1418$.

173. Id.

174. See supra notes 55-56 and accompanying text.

175. See supra notes $20-29$ and accoinpanying text. 
tween his twenty-first and thirty-first birthdays, but he would obtain no benefit from averaging. He could not spread his early high-income years backward, because of the support requirement, ${ }^{176}$ nor could he spread his last high-imcome years forward, smce doing so would require a downward averaging mechanism that Congress elected not to enact. ${ }^{177}$

Congress had reasonably acceptable alternatives to each of these choices that would not have disqualified the taxpayers who were made ineligible by Congress's action. ${ }^{178} \mathrm{But}$, acting principally out of considerations of administrability, ${ }^{179}$ Congress decided to constrict the range of taxpayers eligible for averaging.

Congress made another departure from generahty that was not quite so freely chosen; it had to choose some time frame over which averaging was to be computed. The choice of any such time frame necessarily precluded the choice of all alternative time frames, even though alternative periods might be more advantageous to particular taxpayers at particular times. The rigidity of the period choice, coupled with the mechanical features of the computation-namely, the $\$ 3000$ averagable income threshold ${ }^{180}$ and the thirty-percent base-period income computation ${ }^{181}$ - produce some clear horizontal mequities between taxpayers whose imcome fluctuation patterns happen to fit withm the five-year period and equivalent taxpayers whose fluctuation patterns do not.

This can be seen by examining a few pairs of individuals who are roughly equally situated, but whose eligibility for, and benefits from, income averaging are likely to be quite different. For example, suppose $A$ and $B$ are taxpayers im a creative field, who produce a major work infrequently, but achieve a fairly steady baseline income through the regular production of minor works. If $A$ produces a major work every three years, and enjoys a sizable burst of mcome in such years, he will

176. See Heidel v. Commissioner, 56 T.C. 95 (1971), discussed supra note 55 and accompanying text.

177. Of course, the taxpayer might be able to defer some of his income to lessen his fluctuation penalty, see supra note 138 , but his ability to do so owes nothing to the existence of the incomeaveraging provisions.

178. For example, a simple approach that allowed evcry taxpayer to compute his fluctuation penalty, as defined supra note 3 and accompanying text, and allowed a credit for some fixed percentage of that penalty, would cure both of the probleins identified in this paragraph, as well as the vertical equity problein posed by the threshold amount. See infra notes 205-20 and accompanying text.

179. See H.R. REP. No. 749, 88th Cong., 1st Sess. 112, reprinted in 1964 U.S. CoDE CoNo. \& AD. News $1313,1420$.

180. See I.R.C. $\$ 1301$ (1982), discussed supra notes 52-54.

181. See I.R.C. $\$ 1302(a)(1)$ (1982), discnssed supra notes $30-40$ and accompanying text. 
very likely be able to use income averaging. His base period will consist of one high-income year (from his last major work three years ago) and three low-income years. ${ }^{182}$ If $B$ produces a major work every other year, he is likely to find averaging less helpful, because his base period will include two high-income years and two low-incoine years. ${ }^{183} \mathrm{He}$ may not be able to average at all, ${ }^{184}$ and if he is eligible, he will save relatively hittle because of his larger amount of unaveragable income, compared to A.

The arbitrary nature of the five-year averaging period can also be seen by examining two other taxpayers, $C$ and $D$, who have the following incomes over an eight-year period:

\section{Table IV}

Income by Year (in thousands of dollars)

\begin{tabular}{ccccccccc} 
Taxpayer & 1 & 2 & 3 & 4 & 5 & 6 & 7 & 8 \\
\hline C & 18 & 18 & 21 & 21 & 26 & 26 & 31 & 31 \\
D & 26 & 26 & 21 & 21 & 18 & 18 & 31 & 31
\end{tabular}

$\mathrm{C}$ and $\mathrm{D}$ have identical total incomes, and would be taxed identically under a systein with no averaging, because they have an identical mix of incomes by year-only the distribution among years is different. Presumably, any eight-year averaging system would provide identical relief to $C$ and $D$. Under the present five-year system, however, $C$ will not be eligible for averaging in any of the eight years, but $D$ will be eligible in years seven and eight. In those years, five-year horizontal equity is achieved at the expense of both annual horizontal equity and eight-year horizontal equity.

These two examples illustrate the randomness introduced by a choice of any particular fixed averaging period. Any one taxpayer may find that his fluctuations may be too long, too short, or just right. But this does not produce horizontal equity, unless one is prepared to argue that those whose cycles are just right are the ones inost deserving of relief.

182. If, for example, A produces a major work in year six (and in all other years divisible by three), his base period will consist of years two through five, only one of which, year three, will have been a high-imcome year.

183. If $B$ produces a major work in year six (and in all even-numbered years), his base period will consist of years two through five, two of which, years two and four, will have been highincome years.

184. For example, a taxpayer who alternates years of $\$ 30,000$ income with years of $\$ 50,000$ income will never be able to use income averaging under the present law. His base-period income will always total $\$ 160,000,30 \%$ of which is $\$ 48,000$, which would yield only $\$ 2000$ of averagable income in each potential computation year. 
One last example of similarly situated taxpayers demonstrates that the averaging provisions treat aberrantly good years better than aberrantly bad ones. Again, total incomes are constant, this time over a sixyear period. And each taxpayer has one year in which his income is $\$ 30,000$ higher or lower than that taxpayer's usual imcome:

\begin{tabular}{|c|c|c|c|c|c|c|c|}
\hline \multirow[b]{2}{*}{ Taxpayer } & \multicolumn{6}{|c|}{ Table $V$} & Incoine by years (in thousands of dollars) \\
\hline & 1 & 2 & 3 & 4 & 5 & 6 & Total \\
\hline $\begin{array}{l}\mathrm{E} \\
\mathrm{F}\end{array}$ & $\begin{array}{l}50 \\
40\end{array}$ & $\begin{array}{l}50 \\
40\end{array}$ & $\begin{array}{l}50 \\
40\end{array}$ & $\begin{array}{l}50 \\
40\end{array}$ & $\begin{array}{l}20 \\
70\end{array}$ & $\begin{array}{l}50 \\
40\end{array}$ & $\begin{array}{l}270 \\
270\end{array}$ \\
\hline
\end{tabular}

Taxpayer $F$ has a peak in year five, and can save a significant aunount of tax by averaging in that year. ${ }^{185} \mathrm{E}$ has a valley in the fifth year and cannot average his income in that year. He might hope to average in the followimg year: One aspect of the averaging mechanics that mitigates the prohibition on downward averaging is that a taxpayer's valleys, while ineligible to be computation years, can be base years for some future computation year. ${ }^{186}$ A taxpayer can hope, then, that some part of his fluctuation penalty will be reheved when and if his income rebounds. In this case, however, taxpayer $\mathrm{E}$ will not be able to average in year six, since thirty percent of his income in years two through five is $\$ 51,000$, which leaves him with no averagable income in the sixth year. Nor will he have any averagable incoine im year seven or in subsequent years, as long as his income in those years remains at the normal level of $\$ 50,000$. Taxpayer $E$, then, will never be im a position to reheve any of his fluctuation penalty.

It is clear that none of these similarly situated, dissimilarly treated pairs of taxpayers are handled satisfactorily from a horizontal-equity viewpoint. It is also clear from these examples that it would be more accurate to characterize the present income-averaging mechanism as one that provides relief from fluctuation penalties principally for one type of fluctuation: growth. ${ }^{187}$ The example of the novelist in the pre-

185. D's tax in year five would be $\$ 19,368$ without averaging. With averaging, D's tax liability would be $\$ 18,968$, yielding a savings of $\$ 400$.

186. See supra note 29 and accompanying text.

187. David, Groves, Miller \& Wiegner, supra note 22, at 279 , make this point. Their tentative recommendation is to reverse the approach of the present system, and allow averaging only in years in which there is a reduction in income. Their proposal would certainly be an improvement over the present system. I believe, however, that it makes the same mistake as to downward averaging that the present systein does in the case of upward averaging; it ignores the fact that in many, perhaps most, cases, the annual sacrifice measure is superior to any multiyear sacrifice measure. 
ceding subsection ${ }^{188}$ thus seems an apt example of a taxpayer who is a major beneficiary of the present incoine-averaging system but who has a weak equitable claim to such rehief.

3. Vertical Equity. The least that could be expected of a tax provision not intended explicitly to shift tax burdens away from high bracket taxpayers is that the provision be technically, if not practically, neutral with respect to the income level of the taxpayer. The present imcome-averaging provisions, however, do not satisfy even this mild desideratum. As noted above, ${ }^{189}$ use of an averagable-income minimum of greater than $\$ 3000$ as an eligibility threshold means unambiguously that lower-incoune taxpayers inust experience a greater fluctuation in income, on a percentage basis, to be able to take advantage of income averaging. ${ }^{190}$

The statistics on the incoines of taxpayers who use income averaging apparently reflect this built-in bias, ${ }^{191}$ they may also reflect other, more subtle biases against low-bracket taxpayers. Some analysts have suggested that the coinplexity and appearance of complexity of the averaging schedule prevent those who lack both professional advice and significant education, both of which are presumably correlated with imcome, frons taking full advantage of averaging. ${ }^{192}$ Whatever the causes, statistics on the use of averaging by income groups present a clear pattern. The benefits of income averaging are highly concentrated in the top five to ten percent of the income distribution. Table VI presents data on this distribution. ${ }^{193}$ They show that the dollars saved by averaging per taxpayer increases with incoine. More importantly, they show that the percentage of the aggregate tax liability of each group that was relieved by income averaging is by far the greatest in two income groups: the $\$ 50,000$ to $\$ 100,000$ group and the $\$ 100,000$ to $\$ 200,000$ group. Because these groups respectively constitute the 95.5 through 99.3 percentiles and the 99.3 through 99.9 percentiles of

188. See supra notes $159-66$ and accompanying text.

189. See supra notes $51-54$ and accompanying text.

190. It should be noted that many very wealthy taxpayers never suffer fluctuation penalties, and also obtain no benefit from income averaging, because their incomes place them in the highest marginal rate brackets even in their lowest income years. Thus, a taxpayer who regularly earns $\$ 250,000$ per year will suffer no fluctuation penalty if his incone in one year leaps to $\$ 750,000$. Nor will he be eligible for incoine averaging. This aspect of the tax rate structure explains why it is that the income groups just below the top groups appear to benefit most from income averaging. See supra note 40, and infra notes 194-201 and accompanying text.

191. See infra notes 194-201 and accompanying text, particularly Table VI.

192. See Steuerle, supra note 24 , at 21.

193. The table is derived from 1981 Statistics of INCOME, supra note 10, at $72-75$ (Table 3.1). 
the taxpayer incoine distribution, ${ }^{194}$ it would appear that income averaging in practice shifts tax burdens away from groups that appear quite capable of shouldering tax burdens.

\section{Table VI}

\begin{tabular}{|c|c|c|c|c|}
\hline $\begin{array}{l}\text { Adjusted Gross } \\
\text { Income Bracket }\end{array}$ & $\begin{array}{c}\text { Percentage of } \\
\text { Taxpayers Within } \\
\text { Bracket Who Use } \\
\text { Averaging } \\
\end{array}$ & $\begin{array}{l}\text { Savings } \\
\text { From } \\
\text { Averaging } \\
\text { (in } \\
\text { thousands } \\
\text { of } \\
\text { dollars) } \\
\end{array}$ & $\begin{array}{c}\text { Savings Per } \\
\text { Taxpayer } \\
\text { Who Averages } \\
\end{array}$ & $\begin{array}{c}\text { Percentage of Tax } \\
\text { Liability For Whole } \\
\text { Bracket Saved By } \\
\text { Averaging } \\
\end{array}$ \\
\hline Under $\$ 5000$ & 0 & 0 & $\$ 0$ & 0 \\
\hline $5000-10,000$ & .2 & 5353 & 189 & .1 \\
\hline $10,000-15,000$ & 1.5 & 34,866 & 170 & .2 \\
\hline $15,000-20,000$ & 4.7 & 110,809 & 216 & .5 \\
\hline $20,000-50,000$ & 15.1 & $1,655,285$ & 370 & 1.1 \\
\hline $50,000-100,000$ & 34.5 & $1,293,905$ & 1083 & 2.5 \\
\hline $100,000-200,000$ & 26.2 & 508,184 & 3778 & 2.3 \\
\hline $200,000-500,000$ & 16.2 & 220,411 & 11,602 & 1.7 \\
\hline $500,000-1,000,000$ & 13.1 & 54,730 & 28,490 & 1.3 \\
\hline $1,000,000+$ & 10.6 & 35,897 & 64,796 & .7 \\
\hline Total & 7.3 & $3,919,441$ & 597 & \\
\hline
\end{tabular}

There is, of course, one obvious conceptual objection to this generalization, and, indeed, to the validity and usefulness of Table VI. Because the income-averaging structure permits averaging only in years when the taxpayer's income is high relative to prior years, we cannot, on the basis of the data in Table VI alone, be certain that we have correctly identified the taxpayers who benefit from averaging in terms of their normal income brackets. The apparent prosperity of averagers may be a very temporary condition.

Rebutting this possibility conclusively is difficult, but there is much evidence that suggests that averagers are approximately as prosperous on a long-term basis as they are in the year or years in which they average. Working with a data file that is more complete than any publicly available, one study found that, among taxpayers who used income averaging in any of the years 1967 through 1970, thirty-four percent used averaging in at least two consecutive years, while about fourteen percent used averaging in three consecutive years and five percent used averaging in four consecutive years. ${ }^{195}$ For these taxpayers, taxable incoine in any given computation year may understate their

194. Id. at 34 (Table 1.1).

195. See Steurele, supra note 24 , at $22-23$. 
long-term prosperity; their incomes are not fluctuating but rather are growing. Overall, this study found that the average 1971 taxable income of all people who elected averaging in 1970 was only $\$ 1929$ less than their average 1970 taxable incoine, ${ }^{196}$ suggestimg that this group was about as well off in the year after they averaged as they were when they elected averaging.

It is also possible to gauge the prosperity of averagers in their base periods, rather than by looking at their subsequent income levels. Although this cannot be done with great precision, one can infer, froin the savings from averaging reported in the Statistics of Income, the averagers' approximate base periods. For example, in 1981, income-averaging taxpayers in the $\$ 50,000$ to $\$ 100,000$ income group had mean adjusted gross imcoines of $\$ 64,333$, mean taxable incomes of $\$ 53,123$, and inean tax savings from income averaging of $\$ 1083.197$ This imcome bracket is of particular interest for three reasons: (1) this is the income group for which income averaging accomplished the greatest percentage abatement of tax liability otherwise owed; (2) this is the imcome bracket in which the highest proportion of taxpayers use income averaging; and (3) this is the income bracket in which the median dollar of incoine-averaging tax savings falls. ${ }^{198}$ Using a taxpayer with the mean tax savings and mean taxable mcome within this bracket as the paradigm, one can reconstruct the base-period income consistent with that amount of savings. The total base-period income consistent with the data is $\$ 111,123.199$ Because there was substantial inflation from 1977 to 1980 , this base-period income must be adjusted to be compared with the 1981 income. The result, in 1981 dollars, is that our paradigmatic averaging taxpayer had an average annual taxable incoine over the four-year base period of almost $\$ 36,000$, which is comparable to an adjusted gross income of about $\$ 45,000.200$ This is below that tax-

196. See Steurele, supra note 24 , at 25.

197. 1981 STATISTICS OF INCOME, supra note 10, at 72-75 (Table 3.1).

198. Id. Using linear interpolation, it can be estimated that the 1981 adjusted gross income of the taxpayer who saved the inedian dollar from averaging was about $\$ 56,000$. That is, about half the dollars saved through averaging were saved by taxpayers with incomes higher than that, and about half were saved by taxpayers with lower incomes.

199. Id.

200. The mean consumer price indices for $1977,1978,1979$, and 1980 were, respectively, 181.5 , 195.4, 217.4, and 246.8. The arithmetic mean of this series is 210.3 , which is .772 of the 1981 mean consumer price index of 272.4. STATISTICAL ABSTRACT, 1982-83, supra note 71, at 461 (Table 757). Dividing the $\$ 111,123$ base-period income by the four years in the base period, and dividing that result by .772 yields an average base-period incoine-in 1981 dollars-of $\$ 35,988$. This taxable income figure can be converted into an adjusted gross incoune estinate of $\$ 44,751$, by multiplying it by the ratio of adjusted gross income to taxable income for all taxpayers in 1981. This ratio was 1.243 to 1. 1981 STATISTICS OF INCOME, supra note 10, at 34 (Table 1.1, cols. 8, 11). 
payer's 1981 adjusted gross incoine by more than $\$ 19,000$. It is, nevertheless, about three times the inedian adjusted gross income among all taxpayers in 1981 and would place the taxpayer well within the top ten percent of the income distribution. ${ }^{201}$

Thus, viewing the averaging taxpayer from the viewpoint of both his prior and subsequent income levels provides considerable evidence that, for typical averagers, the coinputation-year income is somewhat higher than income in prior years, but about the same as it will be in subsequent years. Overall, one may reasonably presume that the computation-year incoine of averagers is fairly representative of their prosperity, at least with respect to the immediately surrounding years.

If this presumption is valid, averaging must be viewed as a significant erosion of the progressivity of the tax structure. Table VI speaks for itself: A tax feature that saves thousands of dollars of tax liability for a large percentage of taxpayers in the highest tax brackets, but is substantially unavailable to taxpayers in lower brackets, certamly requires close scrutiny. The distributional consequences inight be viewed as less disturbing and largely incidental if the horizontal equity arguments favoring averaging were powerful. As demonstrated earlier, however, those horizontal equity arguments are seriously flawed. Thus, the burden-shifting effeets of averaging are more difficult to ignore.

\section{Alternatives to the Present Averaging System}

The argument above suggests that outright repeal of the income averaging provisions would save considerable tax revenue, improve the vertical equity of the tax system, and put the horizontal equity of the tax systein on a sounder footing by consistently using an aimual rather than a multiyear standard of measurement. Because immediate and complete repeal is a soinewhat radical suggestion, it may be worthwhile to explore soine alternative ideas for legislative initiatives that are soinewhat more inodest.

The first proposal would change the basic computational mechanics of income averaging. Even if one were to accept as appropriate the multiyear horizontal equity view, it inust be conceded that the present averaging formula produces unnecessarily uneven rehef for incomefluctuation penalties. The first alternative approach proposed ${ }^{202}$ is no

201. 1981 StATISTICS of INCOME, supra note 10, at 34 (Table 1.1, col. 2). This table indicates that $4.2 \%$ of all 1981 taxpayers had adjusted gross incomes in excess of $\$ 50,000$, and that $4.4 \%$ had adjusted gross incoines between $\$ 40,000$ and $\$ 50,000$. The interpolated median adjusted gross income for all taxpayers in 1981 was between $\$ 14,000$ and 15,000 . Id.

202. See infra notes $205-20$ and accompanying text. 
more complicated than the present formula and is considerably more accurate im providing relief. Furtliermore, it could be adjusted to levels that would produce less revenue loss than does the current averaging formula, and could thus be viewed as an alternative to the proposals to this effect presently before Congress. ${ }^{203}$

The second proposal, facilitated by the new formula proposed in the first approach, is for institution of an option to average when income declines precipitously. If one accepts the multiyear view of horizontal equity, one must also concede that the income-fluctuation problem is symmetrical: ${ }^{204}$ downward fluctuations occasion as large a fluctuation penalty as do upward ones.

The third proposal is one that is more consistent with the view presented im Section II of this article, to the effect that an annual assessment of horizontal equity is normally preferable. Recognizing that there are some exceptional cases that deserve relief, however, this third proposal would allow taxpayers in certain exceptional cases to elect a self-averaging device to spread forward the tax burden of large, nonrecurrent items of income received in a single tax year.

\section{A. A New Computational Framework.}

The conventional justiflcation for an averaging system is that a taxpayer whose income fluctuates over a period of years should not bear a larger overall tax burden over that period of years than a taxpayer whose income is more regular. ${ }^{205}$ Yet the computational framework of the present averaging system is not tied im any direct way to the amount of the tax penalty caused by income fluctuation. As noted above, ${ }^{206}$ the averaging system occasionally relieves all, sometimes none, and most often some but not all of the fluctuation penalty, in a pattern that lacks any primcipled basis. At least four problems with the computational system produce this result. The first is that the $\$ 3000$ averagable income threshold needlessly discrimmates against low-income taxpayers, who must experience wider fluctuations of income, in percentage terms, to be eligible for averaging. ${ }^{207} \mathrm{~A}$ related problem, also noted above, ${ }^{208}$ is that the use of any threshold amount, whether

203. See infra notes 259-68 and accompanying text.

204. Indeed, this has been explicitly recognized by several commentators on income averaging, and is disputed by none of whom I know. See David, Groves, Miller \& Weigner, supra note 21 , at 285 , and Steuerle, supra note 24 , at 27 , for an explicit discussion of the need for downward averaging.

205. See supra note 2 and accompanying text.

206. See supra note 30 and accompanying text.

207. See supra note 31 and accoinpanying text.

208. See supra notes 51-54 and accompanying text. 
stated in dollars or percentages, creates points of discontinuity in the rate schedule-points where an additional dollar of income actually lowers tax liability. ${ }^{209}$ The third problem is that using thirty percent of base-period income as the nonaveragable incoine amount, instead of twenty-five percent, the true annual average of base-period incoine, has an unnecessarily erratic effect on the proportion of the fluctuation penalty that will be relieved. If the true average annual base-period income is very close to the boundary of a rate bracket, use of thirty percent as the unaveragable amount may make little difference in the savings from averaging. If there is some distance between the true average and the top of the bracket in which that average income lies, stepping up the unaveragable share to thirty percent in some sense consumes the favorable effect of shifting soine of the computation-year income into that favorable rate bracket. Fimally, the present formula ignores any fluctuation penalty that takes place among the years in the base period. The mecliamism simply compares average base-period income to coinputation-year income, regardless of whether the base-period income itself was regular or erratic. ${ }^{210}$

These problems could be eliminated if the computation method were focused directly on the fluctuation penalty. That is the central msight of this suggestion; a comprehensive resolution of all the associated details will not be atteinpted here. To make this suggestion more concrete, however, the following approach is offered: The taxpayer would first total his taxable incone for the current tax year and the four preceding tax years. ${ }^{211} \mathrm{He}$ would then divide that five-year taxable income total into five equal anounts and compute the tax that would have been owed had the income been received evenly over the five-year period. ${ }^{212}$ This will yield a five-year tax total that would have applied had the taxpayer's incoine been received evenly over the fiveyear period; the total could be called the "zero fluctuation tax."

This could then be compared with the actual tax liability the taxpayer would be exposed to absent averaging. This would consist of the

209. See supra note 54.

210. Of course, fluctuation in the base period may or may not have been partly relieved by averaging in prior years. It will not have been if the taxpayer was ineligible for averaging, or did not have sufficieut fluctuation to average, or had substantial downward fluctuation.

211. There is no inagic in the five-year period, but no compelling reason to change it either, if one insists on using a multiyear period rather than an annual period.

212. This could be computed in either of two ways: The simpler way would be to use current rates, applied to one-fifth of total income, and then to multiply that result by five; soinewhat more complicated, but inore accurate, especially if there is a major rate change during the period, would be to compute each year's tax using the rates that actually applied to each year. Rate schedules for the four previous years could be provided with the instructions to the averaging schedulcs. 
tax already paid in the base period, ${ }^{213}$ plus the tentative tax on the current year's incoine. This total may be called "actual tax." This computation imposes no additional data retrieval burden on the taxpayercompared with the present system-because the taxpayer already must locate his base-year 1040 forms to find base-period taxable income. ${ }^{214}$

Because it would be undesirable to have a system in which virtually all taxpayers were eligible for averaging, a nonnal fluctuation range should be established. This choice should be made by Congress, and should reflect both equity and revenue-loss concerns. For example, Congress might decide that no relief would be available unless the "actual tax" were greater than 1.05 times the "zero fluctuation tax." To control revenue loss, Congress might also decide to limit relief to some certain percentage of the excess of the "actual tax" over 1.05 times the "zero fluctuation tax." Congress miglit decide, for example, to relieve seventy-five percent of the "excess fluctuation penalty." Thus, under this approach a taxpayer would owe an amount-which unight be called "averaged tax"-equal to the tentative tax in the computation year inimus seventy-five percent of the difference between "actual tax" and 1.05 times the "zero fluctuation tax." This is illustrated for a hypothetical taxpayer in Table VII.

\section{Table VII}

\begin{tabular}{|c|c|c|c|c|}
\hline \multicolumn{3}{|c|}{ Actual $\mathrm{Tax}^{215}$} & \multicolumn{2}{|c|}{ Zero Fluctuation Tax } \\
\hline Year & Income & $\operatorname{Tax}$ & Income $^{216}$ & Tax \\
\hline 1 & $\$ 15,000$ & $\$ 1581$ & $\$ 34,000$ & $\$ 5938$ \\
\hline 2 & 35,000 & 6218 & 34,000 & 5938 \\
\hline 3 & 25,000 & 3565 & 34,000 & 5938 \\
\hline 4 & 35,000 & 6218 & 34,000 & 5938 \\
\hline 5 & 60,000 & 15,168 & 34,000 & 5938 \\
\hline Totals & 170,000 & 32,750 & 170,000 & 29,690 \\
\hline
\end{tabular}

Averaged Tax $=$ Tentative Tax -.75 [Actual Tax $-(1.05$ (Zero Fluctuation Tax))]

Averaged $\operatorname{Tax}=15,168-.75[32,750-(1.05(29,690))]$

Averaged $\operatorname{Tax}=13,986$

213. Tax credits should probably be ignored in this computation at all times. Thus, by "actual tax paid," I mean the tentative tax computed before reduction to reflect credits. This would be the amount shown on line 38 of the 1040 Form for 1983, and the comparable line of other year's forms.

214. See supra notes $84-86$ and accompanying text.

215. For convenience, the tax is computed as though the 1984 joint return rates applied to all tax years.

216. This is simply one-fifth of the five-year total for taxable income shown in column 2 . 
Thus, the hypothetical taxpayer has saved $\$ 1182$ of the $\$ 3060$ fluctuation penalty he incurred. The fluctuation penalty was approximately $10.3 \%$ of the zero fluctuation tax; approximately thirty-eight percent of that total penalty was relieved.

Although the present income-averaging structure provides approximately the saine relief in the above example, ${ }^{217}$ the proposed system has several advantages:

(1) The proposed system would relieve thirty-eight percent of the fluctuation penalty of any taxpayer who experienced a $10.3 \%$ fluctuation penalty, regardless of that taxpayer's general income level. In contrast, the present system tends to provide greater relief as income increases. ${ }^{218}$

(2) The proposed system accounts for fluctuation penalties incurred during the base period. For example, if income had been $\$ 27,500$ in each of the first four years, the proposed system would only provide $\$ 565$ of rehief, reflecting the fact that the fluctuation penalty would have been less. In contrast, the present system lumps together all base-period income, regardless of its distribution, and regardless of the fluctuation penalty actually incurred during that period. ${ }^{219}$

(3) The proposed system would relieve none of the fluctuation penalty if it were within a "normal" range, but would relieve more of the penalty the more "abnormal" the fluctuation penalty was. As noted, ${ }^{220}$ the present systein is erratic; it relieves varying amounts of the fluctuation penalties depending on a variety of circumstances, but reflects no principled basis.

\section{B. Averaging When Income Declines.}

If there is, under a inultiyear sacrifice approach, a horizontal inequity problem presented by annual reporting of income, it is likely to be most severe in the case of taxpayers who receive a high proportion of their lifetime earnings within a few years. Actors, athletes, models, and others in the entertainment industry provide the best examples. For successful individuals in these fields, it is the rule rather than the excep-

217. Averaging would reduce computation-year taxes by $\$ 1260$ under present law.

218. See supra notes $193-94$ and accompanying text.

219. An ancillary benefit of the proposed system should be noted: Although a taxpayer in this system could average in consecutive years if he wished to, simply using the "averaged tax" figure rather than the "tentative tax" figure for years in which he averages, there would be some incentive for a taxpayer with fluctuation penalties to average only every five years. All fluctuation penalties are preserved, and are more likely to exceed the $105 \%$ threshold. In contrast, eligible taxpayers must average each year under the present system, or lose the tax savings of averaging for that year. Thus, the proposed system could reduce compliance costs.

220. See supra notes 30-34 and accompanying text. 
tion that their success is dazzling but brief. For those who are welladvised, the decline in income after the peak years can be considerably cushioned. ${ }^{221}$ An individual who has not been able to prepare himself, however, may incur a severe fluctuation penalty.

Nevertheless, that individual may find that the present averaging system provides little relief, especially if his high-bracket years number more than three or four. From the fifth high-income year forward, ${ }^{222}$ the taxpayer will probably be precluded froin averaging by the absence of any low-mcome base years; ${ }^{223}$ when his computation-year income declines from its peak, his averagable income will fall to zero. ${ }^{224}$

The case for extending relief to such taxpayers is quite compelling, and many commentators have noted that the absence of a downwardaveraging device to spread income forward in high-bracket years is a serious shortcommg of the present system. ${ }^{225}$ Certain cominentators would pernit only downward averaging, ${ }^{226}$ arguing that equity considerations are compelling only in such cases. ${ }^{227}$ Nevertheless, Congress has resisted the advice of these cominentators for several reasons, some of which have been discussed earlier. ${ }^{228}$ It may be worthwhile, how-

221. See supra note 159 and accompanying text.

222. If the taxpayer does not have four years of self-support prior to his high-income years, he will be ineligible for averaging even during the first four high-income years. See I.R.C. \$ 1303(c) (1982); supra notes 55-57 and accompanying text.

223. Of course, he may have some relatively low-income years even if his income was high throughout the base period. However, if the relatively low years are absolutely high enough to put the taxpayer in or near the highest marginal tax bracket, then the taxpayer will obtain little or no relief from averaging. See supra notes 126-29, 190 and accompanying text.

224. It should be noted here that computation-year income can decline slightly without necessarily precluding averaging. Because each computation year is compared with the entire base period, and not just the previous year. there are situations where a taxpayer with a declining income-even one which has declined for four years-could be eligible. If a taxpayer's five-year income stream is zero, $w, x, y, z$, respectively, there are combinations of values for those variables in which $w>x>y>z$, yet $.3(w+x+y)+3000]<z$, which means the taxpayer would, if otherwise eligible, be able to average in the fifth year. For example, the sequence $\$ 0, \$ 60,000, \$ 59,000$, $\$ 58,000, \$ 57,000$ would give a taxpayer $\$ 3900$ of averagable incoine in the fifth year-enough to maintain eligibility for averaging. This is not, however, a true counterexample to the point made in the text. In this example, part of the $\$ 57,000$ income in year five is, in effect, being spread back to the first base-period year. It is not the case that the peak years in the middle are being averaged forward to a declining year.

225. See, e.g., Ferguson \& Hood, supra note 21, at 93; Goldberg, Income Averaging Under the Revenue ACt of 1964, 74 Y ALE L. J. 465, 467 (1964); Klein \& Wiegner, Income A veraging for Tax Purposes-Sources of a Statutory Solution, 60 Nw. U.L. REv. 147, 159-61 (1965).

226. David, Groves, Miller \& Weigner, supra note 21, at 279.

227. Messrs. David, Groves, Miller and Weigner are unmoved, as am I, by the plight of the novelist described supra notes $159-66$ and accompanying text, or by arguments that refiect the view that an annual assessment of utility sacrifice is inferior to a lifetime or multiyear perspective. They would abandon the annual view, however, should the novelist's income ever decline significantly. See David, Groves, Miller \& Weigner, supra note 21, at 279.

228. See supra notes 20-29 and accompanying text. 
ever, to review these counterarguments briefly at this point to see which of them may present valid concerns, and how such concerns may be met.

One argument in defense of the present system is that it does offer some relief for downward fluctuations, in the sense that a taxpayer's years of relatively low mcome may become base years for some future averaging computation. This is a limited defense because many taxpayers may not ever return to higher income levels, or may not do so soon enough to mclude the low-income years in a base period for averaging. Additionally, the computational mechanics of averaging operate to adjust upward the base-period years, by using thirty percent rather than the true average of twenty-five percent as the unaveragable mcome. 229 This means that downward fluctuations, even if they are ultimately accounted for in an averaging computation in a subsequent, upward fluctuation year, are systematically disfavored by the present averaging system.

Another major counterargument is that downward averaging amounts to a recomputation of a tax already collected. The present system relieves the high margmal rates that a taxpayer may be exposed to im a year of relatively high income by adjusting the tax in that year. A downward averaging system, on the other hand, relieves high marginal rates not in the high-income year, but in some subsequent year. This is thought by some to threaten the finality of tax collections. One would never know if the revenue collected im a particular year would remain collected or would have to be refunded because of subsequent events. That unknown contingent claims might be attached to revenue for a particular year is thought by some to be undesirable.

This view, however, is difficult to defend given that: (1) virtually every dollar of corporate incoine tax collected is subject to refund if loss carrybacks 230 develop im subsequent tax years; (2) several Code sections that apply primarily to individuals also allow for refunding a prior year's tax payment; ${ }^{231}$ (3) taxpayers may generally amend their returns within the three-year statute of limitations; ${ }^{232}$ (4) the tax year of most individuals - the calendar year ${ }^{233}$ - does not match the fiscal year

229. See supra note 185 and accompanying text.

230. 1.R.C. $\S 172$ (1982). This section also applies to individuals, but, for a variety of reasons, is of benefit mostly to corporations.

231. See, e.g., I.R.C. $\S \S 1311,1341$ (1982).

232. I.R.C. $\S 6501$ (1982).

233. Approximately $99 \%$ of individual returns are for the calendar year. See 1981 STATISTICS of INCOME, supra note 10, at 11. 
used by the government for budgetary purposes; 234 and (5) most taxpayers' earnings are overwithheld and therefore those taxpayers receive refunds anyway. ${ }^{235}$ It would not seem to be a matter of great significance whether the refund is of tax withheld in the prior calendar year or tax paid in some reasonably recent prior year.

It is true that downward averaging might actually produce a negative tax hability in a computation year. Even that, however, would not be unprecedented, because there are other sections of the Code in which prior payment of a tax can be refunded in a year in which there was no tax hability.236 Furthermore, if the "negative tax" feature of this proposal were thought to be undesirable by Congress, it could easily provide that averaging could be used to reduce tax hability, but not below zero. ${ }^{237}$

A more serious objection to general downward averaging is the "floodgates" problem. Downward fluctuations are experienced by most people at retirement ${ }^{238}$ - especially if fluctuations are measured, as they are for income-averaging purposes, in terms of taxable incoine, which excludes most Social Security payments. ${ }^{239}$ This problem is more a practical objection to downward averaging than a principled one. It does not deny that retirees imcur fluctuation penalties; it merely suggests that such penalties are so common, and so costly to reheve, that the problem is one that must be endured.

There are two possible responses to this. First, as a matter of fairness, ${ }^{240}$ one may argue that if the government beheves relief of fluctuation penalties is appropriate, it ought not to carve out specific groups for less favorable treatment without some principled reason for such an exception. And, as a practical matter, it may be that modest adjust-

234. The federal government has, since 1975 , operated on a fiscal year beginning each October 1.

235. See supra note 27.

236. This is clearest, perhaps, in I.R.C. $\S 1341(b)(1)$ (1982), but it is also possible under I.R.C. $\S \S 172,1311$ (1982).

237. Such a provision would have a counterpart in the present averaging provisions, which do not allow negative base-period income. See Title Insurance \& Trust Co. v. United States, 654 F.2d 604 (9th Cir. 1981); Beckman v. United States, 396 F. Supp. 44, 51 (D. Kan. 1975).

238. Pechman mentions this as the principal objection to downward averaging. See J. PECHMAN, supra note 58, at 122.

239. The Social Security Ainendinents of 1983, Pub. L. No. 98-21, § 121, 97 Stat. 65,80 (codified at 26 U.S.C.A. $\$ 86$ (1984)), effective for benefits received after December 31, 1983, have made a portion of Social Security payments taxable to the recipient.

240. The fairness point here is soinewhat blunted by the fact that nost people eventually retire. As noted, supra note 57 and accompanying text, this situation may resenble the tax consequences of Congress's decision to disallow conmuting expense deductions. However, this does not completely answer the fairness concern; all retirees do not incur the same fluctuation penalty, so disregarding everyone's retirement fluctuation penaity does not treat everyone equally. 
ments-such as requiring that tax-favored benefits be added back to the coinputation-year income for purposes of computing a fluctuation penalty-could significantly reduce revenue loss.

Alternatively, one inight concede that retirees should be excluded, but argue that it does not follow that individuals who are not retired should be precluded froin downward averaging simply because there is a perceived need to exclude retirees from relief of fluctuation penalties. Congress removes retirees fron benefited classes when it perceives the need, even in the context of the Internal Revenue Code. For example, one of the conditions for deduction of moving expenses is that the taxpayer be a full-time enployee or perform services as a self-einployed individual on a full-time basis. ${ }^{241}$ Similarly, Congress has effectively precluded retired spouses from the benefits of the "marriage penalty" relief provisions by defining the qualified earned income on which the deduction is based in a manner that excludes pensions, annuities, and similar payinents. ${ }^{242}$ Of course, a pure employment test may not be the best approach in this case, because downward averaging may be most needed by disabled or unemployed individuals. The optimal solution nay be to create a coinbined age and employment test, by which a taxpayer under the age of sixty is presumed to be in the labor force, while those above that age could average only if they were actually still in the labor force. ${ }^{243}$ This would resemble the provisions in the support test that establish a presuinption of self-support for taxpayers over age twenty-five who have not recently been students. ${ }^{244}$ In any event, the retiree problein is not an insurmountable barrier to the extension of averaging relief for downward fluctuation. The difficulties could either be tolerated, by allowing retirees to average, or surmounted, by writing retirees out of the downward averaging proposal.

Fimally, there are two pragmatic arguments against immediate changes in the present system. First, the averaging mechanism would require massive alteration to permit downward averaging, because the present central concept of "averagable income" cannot accomplish downward averaging. Second, implementing downward averaging would increase revenue loss at a time when Congress is attempting to prune such losses wherever it can, including those associated with the

241. I.R.C. $\S 217(c)(2)(A)-(B)(1982)$.

242. I.R.C. $\$ 221(\mathrm{~b})(2)(\mathrm{A})(1982)$.

243. Explicit discrimination by age is not uncommon in the Code. The averaging provisions themselves contain one example; the I.R.C. $\$ 1303(\mathrm{c})(2)(\mathrm{A})$ (1982) exception to the support requirement is unavailable to individuals under age 25 . The additional exemption for taxpayers over age 65, I.R.C. $\$ 151(c)$ (1982), and the capital gain exclusion for sale of a personal residence by a taxpayer over age 55, I.R.C. $\$ 121$ (1982), are other examples.

244. I.R.C. $\S 1303(\mathrm{c})(2)(\mathrm{A})(1982)$; see also supra notes $55-57$ and accompanying text. 
present averaging systein. ${ }^{245}$

The response to these problems is straightforward: The averaging mechanisin needs a complete overhaul. It must be retooled to focus on the major goal-relief of fluctuation penalties. A redesigned computational framework could comfortably accommodate a downward averaging mechamisni. The computational framework suggested in the preceding subsection, ${ }^{246}$ for example, would work as well for downward averaging as for upward averaging. A taxpayer would simply compute his fluctuation penalty-which he may have incurred for fluctuations in either direction, or even both directions in different yearsand proceed to derive the amount by which current tax may be reduced.

Congress could also control the revenue loss problem if it implemented a new computational device. Using the computational model of the preceding subsection, Congress could control revenue loss by adjustment of two key variables: the percentage fluctuation penalty that would be considered normal, below which no relief would be available, and the percentage of "excess fluctuation penalty" that could be credited agamst the current year's taxes. For all of the reasons advanced in this article, Congress would be quite justified in setting these variables at levels that provide only partial relief; the total dollar amount of relief available for fluctuation penalties could thus be considerably constricted. If that is done, however, it becomes all the more important that a computational nechanism be designed to deliver that rehef to the most deserving taxpayers. This group clearly includes taxpayers whose incomes have significantly and abruptly declined.

\section{Taxpayer Averaging Accounts.}

The analysis above argues that horizontal equity is best evaluated annually, because taxpayers typically conduct their lives in accordance with assumptions that are heavily influenced by their present situations. The typical taxpayer lacks any certainty regarding future incoine changes and thus at any given time has an ability to pay tax that is best measured by his annual income.

There are, surely, individual cases in which the premise of this arguinent is demonstrably false. The best example is Goldstein v. Commissioner, ${ }^{247}$ in which the taxpayers, seventy year-old Tillie Goldstein and her retired husband, had mcome in 1958 of $\$ 780$ from his pension,

245. See S. Rep. No. 2062, 98th Cong., 1st Sess. 41 (1983).

246. See supra notes 203-20 and accompanying text.

247. 364 F.2d 734 (2d Cir. 1966). 
$\$ 124.75$ from interest on savimgs accounts, and $\$ 140,218.75$ from a wimning Irish Sweepstakes ticket. As the court drolly noted, this last item "significantly improved petitioner's financial situation."248 The taxpayers recognized the nonrecurring nature of this income itein, and, in consultation with their accountant son, engaged in a series of leveraged mvestments, whose principal object was to generate enough interest prepayments to reduce the 1958 taxable income to approximately half of the gross annount. There were, of course, no general income-averaging provisions in 1958. ${ }^{249}$ Even the present averaging mechanism would have only partially reheved the Goldsteins' problem. Cases like Goldstein, and perhaps a broader range of cases for which Goldstein inay serve as a metaphor, 250 seem to present the strongest case for income averaging. ${ }^{251}$ It does not appear that there was any abrupt leap in the Goldsteins' consumption pattern. ${ }^{252}$ What they really needed was a provision that would permit them to annuitize the lump-suin received in 1958 over their joint remaining lives-a period of some eighteen years ${ }^{253}$ - so that the income mclusion would approxinnately match the expanded consumption opportunities that the sweepstakes winnings afforded them.

One approach to these cases would be to replace the present income-averaging provisions with a self-averaging device-one that would perinit future Tillie Goldstems to bring lump suins imto their taxable mcome streams gradually, thereby avoiding exposure to margi-

248. Id. at 736 .

249. Indeed, because gambling winnings were excluded from the averaging provisions until 1969 , the amounts received here were paid 11 years too early for averaging. I.R.C. $§ 1302$ (b)(3) disallowed wagering gams from the benefits of averaging until it was annended by the Tax Reform Act of 1969, Pub. L. No. 91-172, 83 Stat. 487, 586-87.

250. The lottery "metaphor" may not really be a metaphor at all, because its literal truth may be of a higher order than its representational truth. That is, the lottery is the best example, and may be the only pure example of a large, nonrecurring receipt which is not associatcd with any mcreased expectation of similar receipts in the future. One who writes a successful book, one who wims a contingent-fee lawsuit, or even one who picks the winner of the Belmont Stakes is likely to behieve that elements of skill, the existence of which are verified by the success in the current year, are likely to produce similar results in future years. It may be possible, however, to divide the fruits of the current-year success into recurrent and nonrccurrent portions. The novelist may feel able to produce another successful book, but perhaps not one that is quite as successful as the one in the current year. The lottery winner can represent the novelist at least as to the incrcmental success that is viewed as nonrecurrent.

251. The strength of the equitable claim for bracket relief lias been recognized by Congress in at least one situation: lump-sum distributions from qualified pension plans, which are allowcd a special ten-year averaging. See 1.R.C. \& 402(e) (1982).

252. The Tax Court opinion in Goldstein indicates only that the proceeds were "deposited . . . in a New York bank." 44 T.C. 284, 286 (1965).

253. This is the jomt and last survivor life expectancy for a pair of 70 year-olds. Treas. Reg. $\S 1.72-9$ (Table II) (1983). This calculation assumes that both of the Goldstems are 70 years old; the opinion noted only that Tillie was 70 . 
nal tax brackets that are higher than a true assessment of the taxpayers' multiyear mcomes would justify. Only in this situation does a multiyear approach seem reasonable, because the taxpayer is clearly aware of the nonrecurrent nature of the lump-sum payinent.

The self-averaging device proposed here would be modeled on the present Individual Retirement Account (IRA) provisions. ${ }^{254}$ As with IRA's, accounts for this purpose could not be commingled with any other assets of the taxpayer and would have a special designationperhaps "Taxpayer Averaging Account" (TAA). Eligible for contribution would be any TAA deposits up to the amount by which the taxpayer's tentative taxable income for the current year, computed without any TAA deduction, exceeds some percentage-140\%, for example- of average taxable income in some preceding period of years. Thus, if the four preceding years are chosen as the appropriate base period and total taxable income in that period is $\$ 100,000$, and if the taxpayer has taxable income in the current year of $\$ 50,000$, he could contribute up to $\$ 15,000^{255}$ to a TAA for the current tax year. The contribution actually made would then be allowed as a deduction in the current tax year. As in the case of IRA's, deductible contributions to TAA's should be allowed with respect to a tax year as long as they are made before the due date of the return for that year. ${ }^{256}$

The amount contributed into the TAA would be brought back into income in future years. There are at least three ways to accomphsh this. First, it could be brought back in as the taxpayer withdraws the funds. Second, it could be brought back into income in accordance with a schedule that the taxpayer would be required to file at the time of the deposit. Third, it could be brought back into income in accord with a statutory schedule that required, for exainple, twenty percent mclusion each year for a five-year period. ${ }^{257}$ To avoid the unlimited deferral possibilities of the first two options, Congress might wish to set some minimum annual mclusion percentage. In any of the three options, it would be sensible to tie income inclusion to fund release; that

254. I.R.C. $\$ 219$ (1982).

255. $\$ 15,000$ equals tentative current-year taxable income $(\$ 50,000)$ less $140 \%$ of average baseperiod taxable income $(\$ 35,000)$.

256. I.R.C. $\S 219(\mathrm{f})(3)(\mathrm{A})$ (1982) permits IRA contributions to be made on this basis.

257. I.R.C. $\$ 402$ (e) (1982), the averaging provision for Iump-sum distributions from qualified pension plans, embodies an approach that is somewhat similar, in that the incoine is treated as though it were received in $10 \%$ pieces for purposes of settiug the marginal rates to which the lumpsum will be exposed. The preseut proposal takes a different tack, since it seems preferable to require that the excess receipts actually be set aside to verify that the taxpayer is annuitizing these amouuts, and that the amounts be taxed at the actual marginal rates applicable to that taxpayer in subsequent years to make this device unattractive to those whose incoines are growing, rather than irregular. 
is, if twenty percent of the TAA is income each year, the taxpayer could withdraw up to that amount each year without penalty.

Absent any special provision to the contrary, this approach would involve not only a bracket advantage to the taxpayer, which is of course the point of the proposal, but also a tax deferral. Income would appear on tax returns in years subsequent to its actual receipt. To avoid conferring this additional deferral advantage on taxpayers, the provisions embodying this proposal should compel taxpayers to coinpute the additional subsequent year's tax that results from TAA inclusions and to pay interest on that amount from the year of the original receipt of that income.

It inust be admitted that this proposal, while conceptually appealing, is not without some practical comphications. These provisions, however, are not intended to be used by any large number of taxpayers; they are intended only to initigate any inequities in the proposal to repeal the present averaging provisions. There do seem to be some taxpayers - those who are in Tillie Goldstein's position, in particular-for whom the absence of any averaging device would be a hardship. The TAA proposal is an attempt to provide a limited amount of relief for such individuals. To inake use of these provisions, taxpayers would have to be willing to deal with soine complexity-although it would not seem to be an unmanageable amount. They would also have to be willing to certify their recognition of the nonrecurrent nature of their current-year inconse by putting it out of their reach in a TAA until it became taxable. The device is designed to be unappealing to those who presently are the primary beneficiaries of averaging-those whose incomes are growing year-by-year ${ }^{258}$ - by providing certani dismcentives. Charging interest on the tax deferred controls deferral; segregated accounts with early-withdrawal penalties limits investment possibilitics; and a taxpayer with a growing income will obtain no bracket advantage-indeed, he may incur a penalty-from nooving taxable inconie to a later year.

\section{CONCLUSION}

In their twenty-year history, the federal general income-averaging provisions have grown from a little-understood and little-used relief measure to a major tax reduction device used mainly by taxpayers whose incomes are large and growing. That device costs the Treasury more than four billion dollars per year. The sole reason for these provisions is the view that the horizontal equity tax policy criterion re-

258. See supra note 24. 
quires that taxpayers whose incoines over a five-year period are equal should be taxed equally, regardless of the distribution of incoine among the five years in the period.

This article, however, has deinonstrated that a progressive tax will not necessarily tax excessively taxpayers whose incomes fluctuate, if their tax is ineasured-as it should be-in terms of utility sacrifice rather than in terms of dollars. The period over which assessments of utility sacrifice are to be made is essentially arbitrary, but an annual period appears to be more satisfactory in most cases than any particular multiyear period. The article has also demonstrated that, even if the multiyear viewpoint is correct, the present computational framework is so seriously flawed that the averaging provisions do little in practice to improve the horizontal equity of the federal income tax, and slightly lessen the vertical equity of that tax.

Earlier in the article, the averaging provisions were evaluated in terms of various "pragmatic" tax policy criteria-tlose dealing with aspects of the tax system other than its fairness. The conclusion of this analysis was that, other than the sizable revenue loss caused by incoine averaging, there are no strong policy objections to the averaging provisions. On the other hand, analysis of tlie pragmatic policy criteria suggested no significant justifications for the averaging provisions either.

The article identified one group of taxpayers for whom income averaging may alleviate considerable unfairness: taxpayers who receive large, nonrecurring incomes in a single tax year under circuinstances that suggest that all or part of the income will be annuitized over the taxpayer's remaining life. Cases of this type may not be very numerous, and designing relief for sucli cases that does not also provide relief where none is needed may be difficult. It may well be, therefore, that simple repeal of the averaging provisions is preferable to either the present system or any alternative system. On the other liand, use of a voluntary taxpayer averaging account systein inay provide inexpensive and effective rehef targeted at the nonrecurring lump-sum problem.

Even if, contrary to the arguments in this article, Congress persists in taking a multiyear view of horizontal equity, it should develop a computational system for averaging that focuses directly on the problem it is intended to reheve: the incrennental "fluctuation penalty" incurred by taxpayers whose annual incoines fluctuate.

Fimally, in the interest of consistency-which is really the essence of horizontal equity-Congress should also, if it insists on allowing averaging when a taxpayer's income rises, inake averaging available when a taxpayer's income declines. 


\section{AFTERWORD}

On July 18, 1984, shortly before the final printing of this issue, the President signed into law the Tax Reform Act of 1984, enacted as Division A of the Deficit Reduction Act of 1984. ${ }^{259}$ Section 173 of that Act makes two important changes to the income averaging provisions of the Code, effective for tax years beginning after 1983: (1) the defmition of averagable mcome is changed from the present $120 \%$ of average base-period income ${ }^{260}$ to $140 \%$ of average base-period income; ${ }^{261}$ and, (2) the base period for averaging purposes has been shortened from the four tax years preceding the computation year ${ }^{262}$ to the three tax years preceding the computation year. ${ }^{263}$

These changes will not fundamentally alter the structure of the averaging provisions. They will, however, reduce both the number of taxpayers who will be eligible to average and the dollars saved due to averaging for those taxpayers who remain ehgible. Congress estimated that the revenue saved by this change would be $\$ 133$ million in fiscal year 1984, $\$ 1.994$ billion in fiscal year 1985 , and $\$ 1.886$ billion in fiscal year 1986.264

If one accepts the thesis of this article-that mcome averaging is a largely uimecessary and somewhat expensive device, benefiting mainly upper-bracket taxpayers-then one can only applaud any curtailment of averaging, mcluding that which will be accomplished by the Tax Reform Act of 1984. On the other hand, if convinced of the soundness of those arguments, one must regret the fact that Congress, has, in effect, chosen to pass up an opportunity to enact any true reforuns in the income-averaging area. 265

259. Pub. L. No. 98-369, 98 Stat. 494 (1984).

260. I.R.C. $\$ 1302(a)(1)(1982)$.

261. Tax Reform Act of 1984, Pub. L. No. 98-369, \& 173(b), 98 Stat. 494, 704 (1984) (to be codified at I.R.C. $\S 1301)$.

262. I.R.C. $\$ 1302$ (c)(2) (1982).

263. Tax Reform Act of 1984, Pub. L. No. 98-369, $\S 173$ (a), 98 Stat. 494, 703 (1984) (to be codified at I.R.C. $\$ 1302(\mathrm{c})(2))$.

264. Committee on Ways and Means, Supplemental Report on H.R. 4170, H.R. Rep. No. 432, 98 Cong., 1st Sess. 1386 (1984) [hereinafter Supplemental Report]. Though the amendments will be effective for tax years beginning in 1984, Congress apparently expects relatively modest revenue savings in fiscal year 1984. This is presumably due to two factors: (1) there is a slight mismatch between the federal fiscal year and calendar years (fiscal year 1984 began on October 1, 1983); and (2) most of the revenue loss froin averaging takes place in the form of refund checks mailed back to taxpayers in the spring of the year following the year in which they use incoine averaging, rather than through lower withholding over the course of the computation year itself. See supra note 26.

265. Seasoned observers of the legislative process know better than to assume that what takes place in a "Tax Reform Act" constitutes tax reform. Perhaps this is especially true in 1984. 
All of the basic structural problems will persist. Averaging relief will continue to be based on an artificial formula that bears only a rough and erratic relationship to fluctuation penalties. The $\$ 3000$ threshold will remam, meaning that it will continue to be true that lowincoine taxpayers must experience greater income fluctuations than high-income taxpayers to be eligible for averaging. The forınula continues to permit income changes due only to inflation to be added, in effect, to fluctuations of real income-a problem which will assume even greater importance once indexing takes effect, ${ }^{266}$ because indexing will eliminate the inflation component of fluctuation penalties. ${ }^{267}$ Discrimination agamst taxpayers wlio experience fluctuation penalties because of downward mcome shifts will continue. And, worst of all, relief will continue to be premised on a multiyear view of the appropriate level of sacrifice, witliout any showing that sucli a view is justified. The examples in the text of each of these shortcomings continue to be valid, although the numbers, of course, will be altered somewhat by the altered paraineters of the averaging formula.

The sense that Congress lias inissed an opportunity to address these issues is strong, in light of the fact that this part of the Code is not one that Congress visits frequently. ${ }^{268}$ One's regrets are teinpered somewhat, however, by the reflection that this may not have been the best year to focus on major structural reform to income averaging. The point of this bill seems to be to shake out whatever loose change can be found in the furnislimgs of the tax system, not to replace those furnish-

266. Under present I.R.C. $\$ 1(f)(1)$ (1982), the first indexed-rate structure will be effective for tax years beginning in 1985 .

267. The averaging coinputation employs the rates for the computation year and, in effect, projects those rates backward along with the averagable income that is spread back to the base period. This is a modest problem under the present system, but it will assume more significance under the indexed system, where each set of rates is specifically and uniquely developed for each new tax year. Thus, under an indexed system, a taxpayer with income in 1985 of $x$ could have increases in subsequent years that precisely inatched the infiation rate of $r$. He would experience no fluctuation penalty: indexing would keep both his average and inarginal rates constant. But, if $x$ and $r$ were sufficiently large, he would be able to use income averaging, and would reduce his tax liability by projecting the lower tax rate of the coinputation year to the averagable income. Congress was certainly aware of this problem when it considered the Tax Reform Act of 1984; indeed, this problem was part of what motivated the averaging amendments. Supplemental Report, supra, note 264 , at 1385 . However, Congress has done nothing directly dealing with this problein, except to raise the mininuin $x$ and $r$ that will produce the effect noted purely from inflation. If we have inflation, then, those taxpayers who are eligible to average will obtain an inappropriate benefit to the degree that their fluctuation represents inflation: to that degree, any incipient fluctuation penalty will have been relieved by indexing; averaging will provide a double relief.

268. The only prior congressional amendments to the averaging provisions other than minor conforming ainendinents took place in the Tax Reform Act of 1969, Pub. L. No. 91-172, § 311, 83 Stat. 487, 586-87 (amending I.R.C. $\S \S 1301-1304$ ). 
ings with anything fundamentally different. More importantly, the possibility-although it's a faint one-that the next Congress may enact a genumely flat tax rate schedule may drain Congress of any enthusiasm it might otherwise have to study closely those problems that a flat tax would obliterate. Income-fluctuation penalties are such a problem. One can only hope that after the graduated rate structure has proven its ability to endure, Congress will then turn its attention once agam to the income-averaging provisions. 